\title{
Ved grænsen
}

Anna Rud Bentholms minder fra Grøngård 1928-57

\section{Ved Lars N. Henningsen}

Gennem en menneskealder, fra 1928 til 1957, bestyrede Axel Bentholm Statens Jordlovsudvalgs store ejendom »Grøngård « i grænseegnen ved Lydersholm i Burkal sogn. Han og hustruen Anna Rud Bentholm fik stor betydning for egnen, både nationalt og økonomisk.

Peder Axel Bentholm var født i Brande den 16. december 1885 og blev landbrugskandidat. Gennem en del år havde han en gård på Århus-egnen, og her blev han i 1918 gift med Anna Johanna Jensen Rud (født 22. februar 1898), datter af redaktør Bertel Jensen, Aarhus Amtstidende. En hel børneflok voksede op i hjemmet i de følgende år: Bertel, født 1920, Svend, født 1922, Inge, født 1928 og Arne født 1930.

I december 1928 blev Bentholm bestyrer på Grøngård, en vanskelig ejendom med sandplagede marker og forblæste bygninger. Et stort arbejde blev udført de følgende år med læplantning og afvanding derved andrede landskabet karakter, og vindens barske herredømme blev mildnet. Gården blev udgangspunkt for opdyrkning af store arealer i området, og i 1931 fik 6 familier bolig på nye husmandsbrug ved gården.

Der blev også tid til et betydningsfuldt folkeligt og nationalt arbejde. Som formand for »Danmarks mindste forsamlingshus $i$ Lydersholm kaldte Bentholm fremragende foredragsholdere og kunstnere til den yderste grænseegn. Hustruen Anna var nok sjælen $\mathrm{i}$ dette arbejde. Anna Rud Bentholm gjorde sammen med sin mand Grøngård til et samlingspunkt på egnen. Hun gik engageret op i det nationale og kulturelle arbejde, og grænsegendarmerne blev kære gæster på gården.

Fru Bentholm førte dagbog, særlig i besættelsesårene, og hun gemte omhyggeligt på papirer af historisk interesse. I 1957 gik ægteparret på aftægt $i$ et hus tæt ved Grøngård, og nu blev der mere tid til at bearbejde og udforme optegnelserne. Efter Bentholms død den 27. juni 1962 flyttede Anna Rud Bentholm til Jejsing, og her fortsatte arbejdet med at skrive om tiden på Grøngård og om gårdens historie. Inden sin død den 24. august 1975 besluttede hun sig for at søge sine optegnelser 


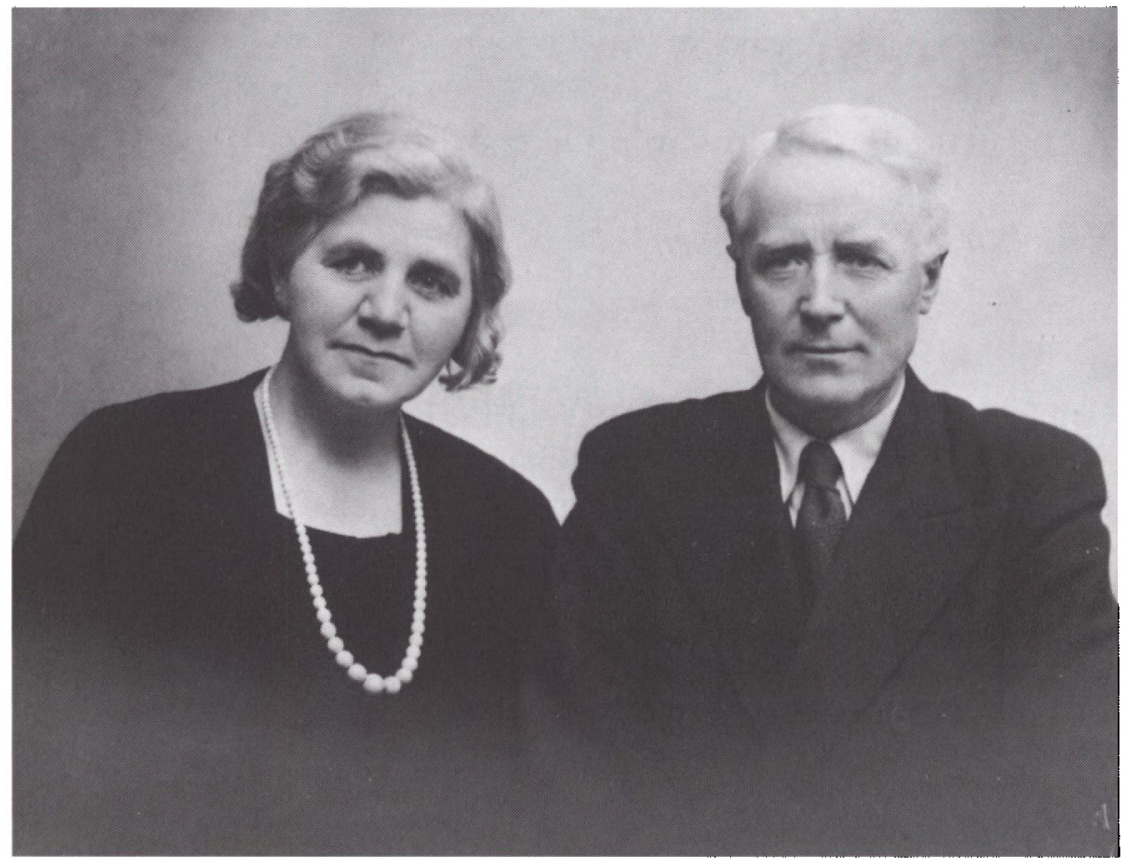

Axel Bentholm og Anna Rud Bentholm. Foto Schwennesen, Tonder. 1930'erne. Privateje.

udgivet. Det sker nedenfor i forkortet og redigeret form. Originalmanuskriptet og supplerende materiale er $\mathrm{i}$ dag bevaret $\mathrm{i}$ landsarkivet $\mathrm{i}$ Åbenrå.

\section{Egnen}

Egnen ved Grøngård er meget vandrig. Strækningen fra Tønder-Flensborg vejen til grænsen ved Bejers kro er knap $4 \mathrm{~km}$ lang, men vejen krydser 5 åer: Grønå, Lillestrøm, Gammelå, Sønderå og til sidst Skelbækken, der danner grænsen. De snor sig gennem det flade landskab, der på sin måde er så skønt, med det vide udsyn over marker og enge.

Fra Jejsing banke er der en strålende dejlig udsigt mod syd. Bag Grøngård skove ses skove ved Vestre i Sydslesvig. Elhøj, Sdr. Løgum og Ladelund skimtes i horisonten.

Grøngård ligger $10 \mathrm{~km}$ øst for Tønder, ca. $2 \mathrm{~km}$ fra grænsen. Den har sin meget interessante historie. Navnet kan føres tilbage til hertug Hans den ældres tid 1570 . Der var dengang over 1000 tdr. land og et 
jagtslot. Det nuværende Grøngård er bygget 1844 af H. L. A. Burchardi, og der lå dengang 4-500 tdr. land til gården.

Ved et mageskifte 1924 overtog den danske stat Grøngård. Den tidligere ejer Eduard Nissen fik Augustenborg Hovedgård.

I efteråret 1928 traf min mand Axel domæneforvalter Refshauge hos min bror redaktør Harald Rud. Axel fik stillingen som domænebestyrer af Grøngård. Han var første gang på Grøngård sammen med Refshauge den 15. dec. 1928.

Vort indtog på en "ødegård"

Mellem jul og nytår rejste Axel til Grøngård med Bertel, 8 år, og Svend, 6 år. Jeg rejste med Inge, 8 måneder, i en klædekurv og ankom nytårsaftensdag ved 2-tiden.

Det var meget strengt vintervejr. Der fandtes ingen fødemidler, ingen tørv eller andet brændsel. Jeg ville fyre i kaminkakkelovnen med sammenskrabede pinde og smuld - den røg! Lukkede så et vindue op - det faldt ud!

Der var petroleums-belysning overalt, og jeg havde aldrig før gjort petroleumslamper i stand. Lampen i kontoret, en slags hænge-køkkenlampe, hang højt lige under loftet $\mathrm{i}$ bøjet ståltråd. Den osede og osede! Først i 1934 fik vi elektricitet, tænk hvilken forandring og lettelse.

Egnen omkring Grongård. Generalstabens topografiske kort. 1921. Målestok 1:100.000.

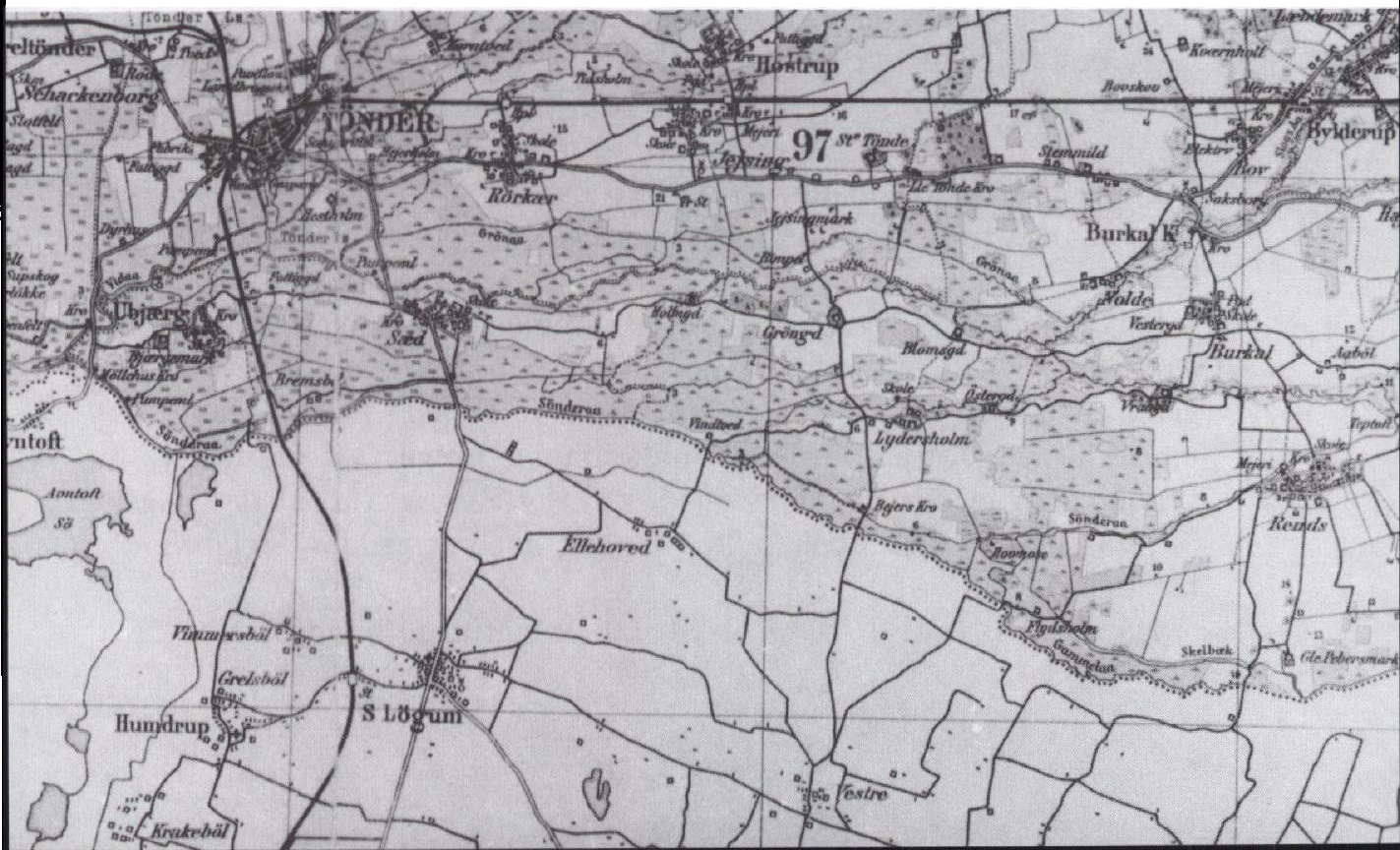


Der var koldt og mørkt, med træk og uhygge alle vegne. Tapeterne var falmede og $\mathrm{i}$ stykker. Vandet til husholdningen skulle vi have $\mathrm{i}$ bryggerset, fra en pumpe til et rør, slået lidt ned $i$ jorden. Pumpen havde et filter. Pumperøret var slået ned lige netop i bryggersets afløbskumme. Når vi havde pumpet en spand vand, skulle det stå lidt og falde til ro. På overfladen kom der olieagtige pletter, nederst plumret grums og så kunne vi bruge det midt i!

Engang prøvede vi at lave te af vand fra en regnvandsbeholder nede ved stalden; men det smagte ikke godt. Vel for at sætte sagen på spidsen berettede Axel om døde katte, fugle, mus og rotter i regnvandsbeholderen.

I foråret 1929 fik vi en artesisk boring udenfor, $15 \mathrm{~m}$ ned $\mathrm{i}$ jorden. Vandet var bedre, dog meget jernholdigt.

\section{Egnen $i$ begyndelsen af vor tid}

Den gamle vej fra Sæd til Grøngård var nok bred, men sandet og havde dybe løse hjulspor. I 1934 fik vi en fast vej fra Sæd hertil. Grænselandsbyen Sæd ligger på overgangen fra marsk til gest ca. 3 $\mathrm{km}$ sydøst for Tønder ad vejen mod Husum, omgivet af enge mod nord, vest og syd. I tiden før afvandingen stod enge og marker oversvømmet af vand hele vinteren igennem, ja, undertiden også om sommeren. Selve byjorden er dog højere beliggende sandjord. Der er en del gårde og mange små ejendomme med lidt jord til. Til hver ejendom er der et jordstykke, en "stavn«. Her dyrkes kartofler, de såkaldte Sæd-kartofler, en slags æggeblomme af ganske enestående fin kvalitet. Ejendommeligt er det, at der år efter år dyrkes den samme sort på samme stavn. Eldre kartoffeldyrkere i Sæd beretter om, at det har været sådan slægtled efter slægtled. I følge en beretning af pastor Kallmer, Faretoft, i et tidsskrift 1796 har der i Sæd dengang "været avlet mange urter og havesager; navnlig gulerødder, og i alt $40 \mathrm{tdr}$. kartofler i hele byen«.

Selv om jorden tilsyneladende er af samme godhed, skelner man dog ganske nøje mellem de stavne, der giver den bedste kvalitet, og de, der giver en ringere kvalitet. Kartoffeldyrkerne i Sæd var nøjsomme og uhyre flittige. Jorden får kun staldgødning. Ifølge gammel tradition vender man jorden med spaden, ja enkelte går så vidt, at de drager plovens nytte for jordbehandling i tvivl, når det gælder dyrkning af kartofler.

Håndens arbejde holdes $\mathrm{i}$ hævd. Inden lagringen håndsorteres kar- 
toflerne 2-3 gange. Det er den bedste garanti for, at der ikke leveres en eneste forkert eller dårlig kartoffel.

Før genforeningen 1920 havde man et gammelt marked for Sædkartofler i Tønder og i Flensborg. Her regnede man med en fast pris af ca. 11 mark pr. tønde. Men dette er forbi nu. Grænsen er lukket for Flensborg, og i Tønder er der kommet kolonihaver. Man ser nu, at enkelte stavne er tilgroet med græs. Den traditionelle kartoffelavl er ude for store vanskeligheder, foldudbyttet er ringe, og det er et stort arbejde med håndkraft.

\section{Sandflugt og laeplantning}

$\mathrm{Da}$ vi kom til Grøngård, var her store sandmarker. Ca. 217 ha af gårdens tilliggende var vide flader uden mindste læ.

Med de stærke forårsstorme fulgte ofte voldsom sandflugt. Orkanens lyd gav søvnløse nætter, og på sandflugtsdage rystedes man til sit inderste. Axel gruer endnu, når han ser det for sig, som det var de første år.

Fint, fint gråt og sort støv trængte sig ind alle vegne, gennem små utætheder $\mathrm{i}$ taget, ved døre og vinduer. Ja, vindueskarmene $\mathrm{i}$ stuen kunne være fuldkommen sorte, ligefrem små sanddriver. Særlig ørerne blev fulde af sand. Karlene var til tider helt sorte $i$ hovederne. Ja, alt og alle var sort!

Luften var tyk. Tit kunne vi slet ikke se nabogården Lille Grøngård ca. $500 \mathrm{~m}$ herfra. Grøfterne røg fulde af sand. Hele plovfurer kunne udslettes. Markerne led stormskade. Tilsåede marker måtte ofte sås om, både roemarker og kornmarker, ikke mindst udlægsmarker og den udspredte kunstgødning. Et år såede vi roer samme sted tre gange. I en tør sommer fik vi kun lille avl.

"Her skal plantes«, sagde Axel. Hvert år blev der plantet et stykke læhegn omkring markerne. Den ringeste sandjord blev plantage. Målt i kilometer blev Axels læplantning over $15 \mathrm{~km}$ ialt. Erfaringen har vist, at på jorden her er det bedste til læ dobbelte rækker af tjørn, med $1 \frac{1}{2}-$ $2 \mathrm{~m}$ mellemrum. Nu kan markjorden få lov at blive liggende. Der kan dannes muld! Herhjemme ved gården er der bøg og lind samt gråasp. »Plant et træ, og du har ikke levet forgæves!«

\section{Afvanding}

Vi hører til grænsebyen Lydersholm, ca. $11 \mathrm{~km}$ øst for Tønder og 1 $\mathrm{km}$ nord for grænsen ved Bejers kro. Om sommeren er vor lille landsby omgivet af blomstrende enge, $i$ vintertiden (inden afvandingen) af vand 
og vand, så langt øjet rækker, idet skytten lukkes for Gammelåen, så engene overrisles. Når det er frost, bliver her en fin fin skøjtebane. Det siges, at man (dengang) kunne løbe på skøjter helt fra Rens forbi Lydersholm til Tønder. Ofte har vi, hele familien, far, mor og børn løbet på skøjter på den dejlige is.

Særlig før afvandingen (1931) kunne det ske, at den nærliggende Grønå gik over sine bredder, fordi vandet østfra pressedes mod vest. Vidåen ved Tønder kunne ikke nær tage vandet. En skønne dag stod over halvdelen af vore marker blanke! I en regnfuld sommer kunne det blive meget besværligt at få bjerget både hø og korn. Der har været regnfulde høstdage (1931), hvor åerne gik over bredderne. Høstakkene svømmede væk, ud i Vidåen, ud i havet!

Atter står det tydeligt for mig, hvordan regnens ensformige lyd kunne holde os vågne om natten, med tankerne på høet og kornet derude på de lave marker. Man blev stille, passede det arbejde, der kunne gøres trods regn, og gik tidligt til ro om aftenen. Kornet druknede eller spirede og groede igen.

Når vi, i de store oversvømmelsers tid, en dag kørte i jumbe til Tønder, stod landevejen ofte under vand lige uden for byen. Gården "Hestholm« ligger på en værft, en stor forhøjning af jord. Her havde folkene altid en lille båd at sejle med de $400 \mathrm{~m}$ over til landevejen.

Grøngård ligger lige på grænsen, hvor afvandingen begynder. Grundvandstanden er sænket med $75 \mathrm{~cm}$. Man siger, det kan mærkes på arealerne helt ovre ved Tinglev. Vi kunne nu jævne et utal af grøfter og kanaler. Engene kunne nu opdyrkes og gav gode afgrøder af havre. Dette fik stor betydning for gårdens drift, som blev lettere, sikrere og bedre. Men det kan dog ske, at der kommer så megen nedbør, at afvandingen ikke kan tage det. Den 7.-8. november 1954 stod Bimpels mange tønder land under blankt vand, helt fra Nolde. Roerne standses i vækst og kan tage skade. 50 vilde svaner, gæs og ænder svømmede på marken i lang tid.

\section{Hohosten}

Skønt at se ud over egnen her $i$ høets travle tid, ganske særlig skønt dernede ved grænsen, hvor høstakke står i tusindvis i eng ved eng, så langt øjet rækker, både nord og syd for grænsen.

Travlheden er overvældende. Om vejret tillader det, bliver græsset slået den ene dag, vendt næste dag og stakket tredje dag. En gammeldags ragemaskine river høet sammen i lange strimler, og så slæbes det 


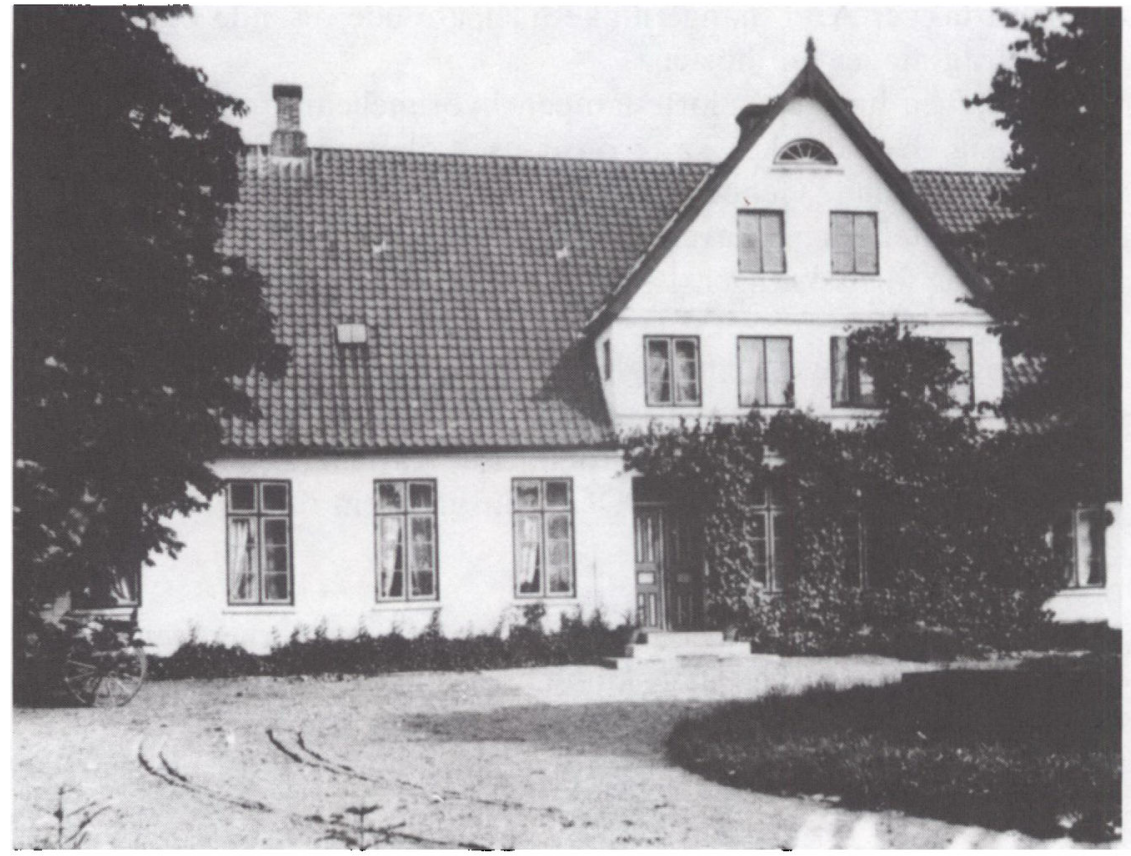

Grongård, stuehuset. (Historiske Samlinger for Sonderjylland)

i dynger af en hest med en høslæber, en lang solid stang eller bræt. Et par mand sætter stakken.

Alle er med. Alle familiemedlemmer hjælper. Mange bønder sydfra ejer jord her nord for grænsen og har tilladelse til at køre over ved Bejers kro med deres vogne for at bjerge høet. Sproget er overalt dansk.

Et betagende syn, en vidunderlig oplevelse at stå dernede ved Skelbækken, eller sidde på grøftekanten, og se ud over de milevide engstrækninger. Ganske særlig skønt ved solnedgang.

På Grøngård havde vi ofte over 300 læs hø, ja, 4-500. Et hejseapparat kunne løfte $\frac{1}{2}$ læs op ad gangen. Så kørte apparatet hen ad en skinne under loftet, og høet blev sluppet løs på den plads, hvor det nu skulle ligge. Ude på gårdspladsen trak en hest tovet, der førte hejseapparatet. Høloftet blev mere end fuldt, laden også.

Alle, der har hjulpet til med høsten, mødes efter traditionen festklædte og med store forventninger til høstgilde. Bordene er smukt pyntede og veldækkede. Der spises vældig god mad og synges høstsange. Som 
husbond takker Axel mange flinke hjælpere ude og inde og kommer med betragtninger om høsten.

I havestuen hænger kulørte lamper, hvorimellem grønne vinranker slynger sig. Der drikkes kaffe og danses til harmonikaens toner til langt over midnat. Gennem den åbne havedør nyder vi stilheden og den dejlige stemning $i$ haven. Axel har selv bygget en hytte $i$ haven, hvor der fås forfriskninger. I smedejernskransen under loftet brænder levende lys.

Engang havde jeg hængt nogle kulørte lamper op ude ved et par af havebænkene. Jeg syntes, det så festligt ud. Men en af drengene sagde: »Nej, mor, det er da vist en misforståelse! Karlene og pigerne ønsker sikkert ikke nogen belysning«. Deres far gav dem ret.

\section{Storken}

Når vi nærmer os april, begynder vi at kigge efter storkereden på den gamle lade. Mon storken snart kommer? Reden har været beboet hvert år, vi har boet her. $\mathrm{Nu}$ gælder det om, hvem der først kan melde: Storken er kommen. Som regel i første uge i april, derfor blev storkemeldingen ofte brugt til aprilsnar.

Det var festligt at følge storkenes liv. Ofte spadserede de ude i haven eller på gårdspladsen for at hente grene eller græstotter til redebygningen. Senere fulgte vi flyveøvelserne med ungerne. Kun et enkelt år fik storkeparret ingen unger. Det skyldtes heftige storkekampe. Ingen vil vel tro, at storke kan være både ondskabsfulde og voldsomme, når det gælder at ødelægge de nylagte æg $\mathrm{i}$ andre storkes reder. Næsten hvert år oplevede vi disse angreb. Til at begynde med kommer de fremmede storke flyvende højt oppe i luften og kredser rundt om Grøngårds storkerede. Vore egne storke skiftes til at ruge. Nu breder den rugende stork vingerne ud og knebrer af fuld hals. Det er »luftalarm « for at kalde magen hjem. Pludselig styrtdykker den fremmede stork, lige ned, og forsøger at skubbe æggene ud af reden med næbbet. Det er hændt, at et æg er røget langt ud i gårdspladsen, helt over på den anden side af flagstangen, ca. $50 \mathrm{~m}$. Vor stork har så begyndt at lægge nye æg og ruge forfra. Det nåedes at få ungerne, gerne 3-4 stk., flyvefærdige, inden de rejser af til de varme lande sidst i september.

Ofte har vi mennesker forsøgt at skræmme de fremmede storke bort, når vi mærkede, at de ville angribe. De reagerede ikke det mindste.

I påsken 1936 kom et helt nyt storkepar og ville bygge rede på den vestlige ende af stuehustaget. Gang på gang forsøgte storkene at fæstne grene og pinde mellem lynafleder-ledningerne. Det lykkedes ikke. Stor- 


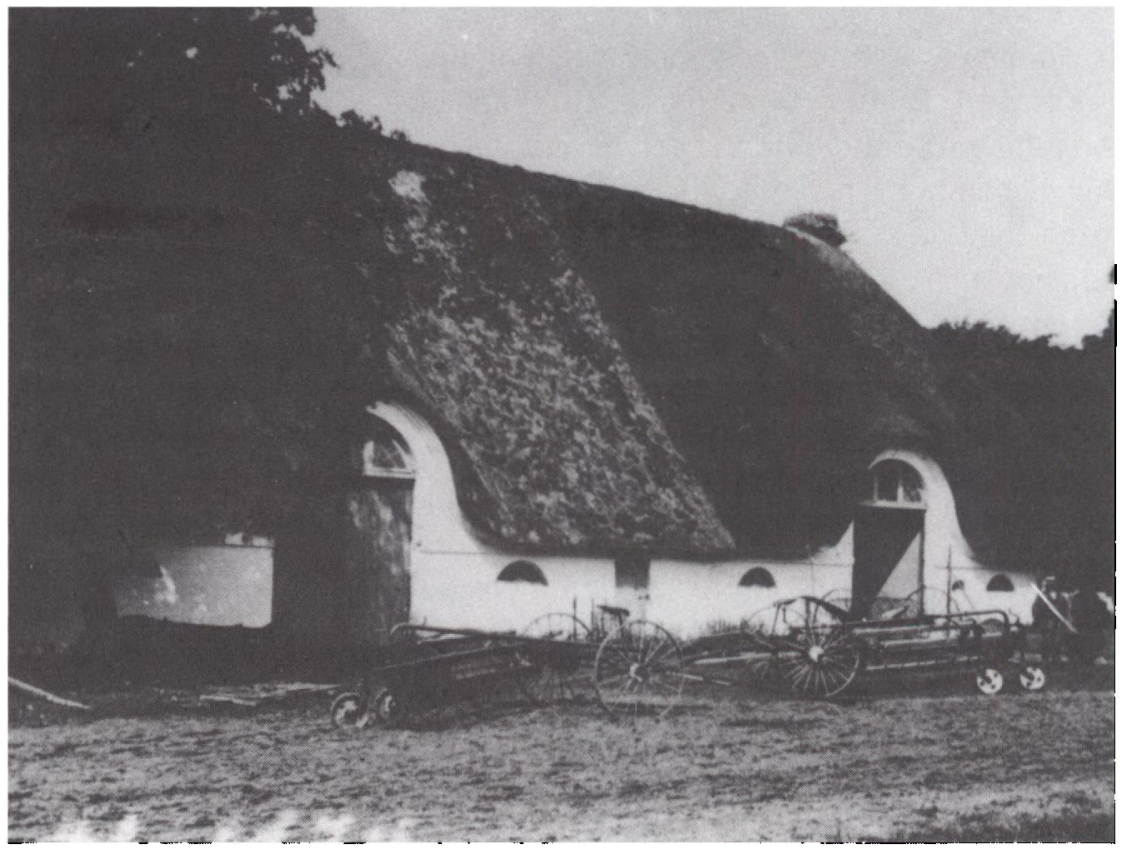

Det valdige stråtag pd̊ Grongdrds gamle lade kronedes af storkereden. (Historiske Samlinger for Sonderjylland)

kene gav dog ikke op. De blev ved. Til sidst forbarmede Axel sig over de nye storke. Han kravlede helt op på det høje tag og fik et gammelt vognhjul anbragt. Nu fik storkene travlt, nu var de glade. Men vort gamle storkepar på ladetaget ville ikke lade dem have fred. De jagede dem ustandselig. Redebygningen blev dog ført igennem, og de fik en eller to unger.

En gang havde vi besøg af storke-eksperten Halfdan Lange. Han så og hørte 25 forskellige fuglearter $\mathrm{i}$ haven. I timevis sad han oppe på ladetaget med en god kikkert. Det gjaldt for ham at få øje på nummeret i en ring, som den ene stork havde om benet. Lange konstaterede, at storken var 16 år gammel og stammede fra Ravns gård i Christiansfeld, $55 \mathrm{~km}$ herfra.

Inden afrejsen i september samledes ofte store flokke af storke. En dag så vi 20-30 storke, der overnattede her, rundt omkring på tage, skorstene og i træer. 
Mund- og klovsyge

I sommeren 1938 hærgede den modbydelige syge på egnen. Når man cyklede til Tønder, så man overalt skilte med »Mund- og Klovsyge! Adgang forbudt! Politiet«. I hver eneste fenne lå syge, syge dyr. Det var gribende og rystende, og vi hjalp alle til med at pleje og passe de arme dyr, da også vore køer på Grøngård blev syge. På flere gårde døde et større antal af de bedste malkekøer. Det gik ikke alene ud over dyrene selv; men modgangen gik også landmændene på nerverne.

Efter den lange afspærringstid føltes det som en befrielse at måtte færdes frit. I vor lettelse over at være sluppet for indespærring besluttede vi, at alle på gården, lige undtagen fodermesteren, der ikke kunne nå at være hjemme igen til røgtetid, skulle cykle en tur langs med grænsen til Flensborg og Kollund.

„Hvor skal I hen?« råbte Thilde Edlefsen ud af sin dør på Hovmose, da vor lille, ret store flok kom cyklende. "Til verdens ende« ...

Det var morsomt at føle sig fri. Vi nød alle at kunne gå rundt $\mathrm{i}$ Flensborg, også handle lidt. På tilbagevejen måtte vi jo ind til tolderne. Dengang var der stor prisforskel på damestrømper i Tyskland og så herhjemme. Jeg havde købt ét par i Flensborg. Det var såmænd alt; men jeg må vel alligevel have nævnt noget om, hvordan jeg skulle få strømperne gennem tolden. Der skete ikke noget. Men da vi var toldbehandlede, dog endnu ikke gået ud, sagde Inge på 10 år ret højt: »Det gik jo godt, mor!«

\section{Tjenestefolk og ferieborn}

Her leves et jæunt og muntert liv. Det gælder for os alle at finde den rette arbejdsglæde. Vi forsøger som husbond og madmor at være livet i hjemmet og bestemme hjemmets ånd. Det ser vi som vor opgave og vort ansvar fremfor noget. Efter natur og evne søger vi at være levende interesseret, sætte os ind i, føle med dem, der søger tjeneste hos os.

Utallige er de mange unge, og aldre med, der er gået ud og ind af hjemmets dør mellem år og dag. Unge medhjælpere her fra landet, og unge medhjælpere, landbrugsstuderende, både fra ind- og udland: England, Skotland, Irland, Frankrig, Finland, Norge. Unge huslige piger fra Holland og Sydslesvig.

Det hjalp på, og fornyede, ens sprogkundskaber. Det var mest engelsk, der anvendtes. For eksempel: en finsk, landbrugsstuderende pige kunne ikke svensk. Anni, vor hollandske pige, ikke et ord tysk. I begge tilfælde klaredes det på engelsk. 
Huang fra Kina må nævnes som husets særlige ven. Han havde hjemme i Shanghai og var sendt herover af Chang Kai-shek-regeringen for at studere kemi, for bagefter at kunne undervise studenter hjemme i Kina. Men den politiske udvikling, med ny kommunistisk regering, gjorde, at Huang blev temmelig lang tid i Danmark. Han turde ikke rejse hjem. Han var Svends studiekammerat fra Farmaceutisk læreanstalt og blev dansk dr. pharm. Han kom her på ferie og talte fint dansk.

Vi modtog også krigens børn på Grøngård. De kom her for at komme til kræfter, komme til ro og trives igen, under forholdsvis rolige forhold, under dansk sol og sund næring. Berit Reiman fra Helsingfors var her i $1 \frac{1}{2}$ år, Wim Wellinga fra Haarlem i Holland i $\frac{1}{2}$ år, Erika Werner fra Flensborg i 4 somre. Dejlige børn var de alle tre, vi havde glæde af dem.

Vi har altid følt, at da vi havde plads, hjælp og mad nok, kunne vi tage et feriebarn fra København, dog ét ad gangen! Vi har haft France Simonsen, Erna Nielsen og Jon Wollesen, hvis far var kaptajn og sejlede syd om Afrika, igennem mange sommerferier. Flinke og søde var de alle tre.

\section{Apuschkins dod og begravelse}

Vor sognepræst (1916-39) her i Burkal var pastor Schwarz, tysk uddannet og tysksindet, for mange af os helt fremmedartet i tale og færd. Schwarz kom tit på besøg ude omkring og var meget flink. Han var interesseret $i$ sine sognebørns daglige liv og virke og ville gerne være god mod alle. Fra 1935 havde vi tillige en dansk præst, N. P. Nielsen, der boede i Højer og udførte de kirkelige handlinger for de medlemmer af den danske menighed i grænsesognene, der ønskede det. Pastor Nielsen var meget jævn og ligefrem, som en ven af os, og vi holdt meget af ham som præst.

Når nogen her i Lydersholm og Grøngård var død og skulle begraves, gik en bedemand rundt til hvert eneste hjem. Det var ofte smed Jacob Mathiesen (æ gammel smej). Han var iført diplomat og høj hat. Det var også skik, at alle gik med til begravelser, både tyske og danske. De fleste gange var der kaffebord i Saksborg kro, lige ved kirken.

I 1937 var det Ivan Apuschkin, som skulle begraves. Apuschkin var født i Bordnikoff nord for Moskva. Han deltog i verdenskrigen 191418 og blev taget til fange i 1915. Som fange kom han til Lydersholm på Grøngård.

Han var malermester og en uhyre flittig mand. Han blev gift med Johanne, f. Walther, fra Rens, og de fik 8 børn. Apuschkin havde i 


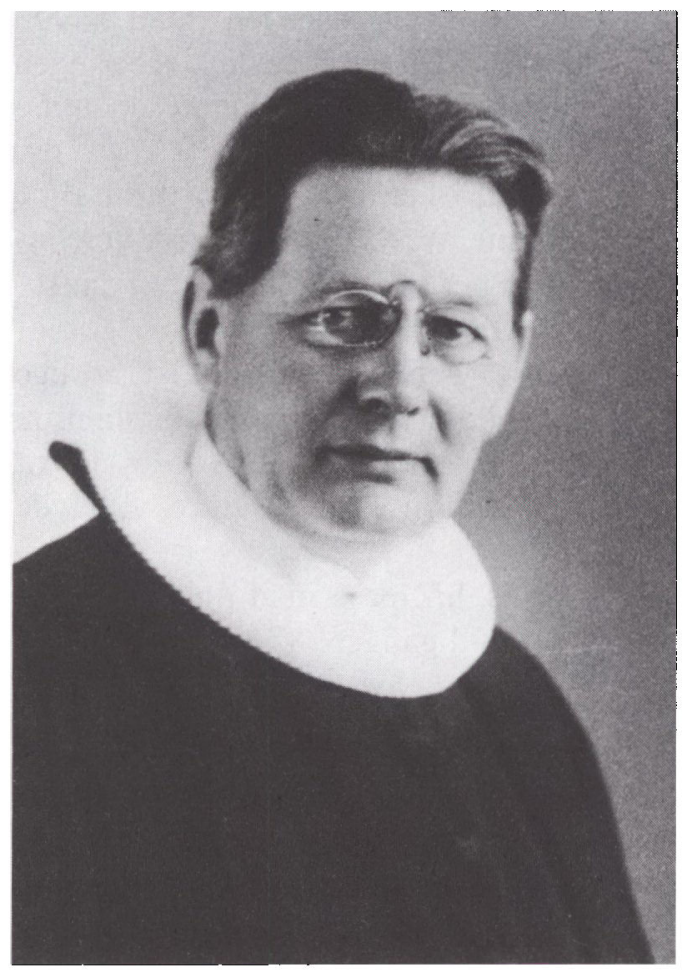

N.P.Nielsen (1885-1982) var fra 1920 sogneprast $i$ Vedsted. I 1935 flyttede han til Hojer som residerende kapellan. Foruden den danske menighed $i$ Hojer og Hojer landsogn havde N.P.Nielsen pligt til at betjene de danske $i$ gransesognene, der måtte onske det. Hans prastegerning omfattede dermed også Daler, Hostrup, Burkal og Øster Højst sogne. (Foto o. 1930, Historiske Samlinger for Sonderjylland).

længere tid lidt af sukkersyge og nyrebetændelse. Han døde i 1937 under svære lidelser.

Under Apuschkins sygdom fik han af og til besøg af begge vore præster, dog kun hver for sig. Fru Apuschkin fortalte, at hun havde aftalt med sin mand, at pastor Nielsen skulle tale i hjemmet, Schwarz i kirken og forrette jordpåkastelsen.

$\mathrm{Da}$ det kom til begravelsen, gik bedemanden rundt og bød ind: " Jeg skal hilse fra fru Apuschkin og sige, at hendes mand er død, og indbyder venligst hermed os alle til at komme og følge den døde til graven 25. september kl. 2 fra hjemmet«.

Pastor Nielsen talte smukt og gribende om afdødes tunge livsskæbne. Han havde været flittig, sparsommelig og pålidelig, respekteret for sin stræben efter at skaffe det nødvendigste til den efterhånden store børneflok. Apuschkin havde længtes efter at gense Rusland. Under store økonomiske ofre rejste han derover for at besøge sine forældre. Barndomshjemmet var $i$ en sørgelig, oprevet forfatning. De havde 
mistet alt, hvad de ejede. Faderen var død, og moderen flyttet til en datter. Apuschkin ønskede sig atter hjem til kone og børn i Lydersholm. Da han skulle rejse hjem, tårnede særlige vanskeligheder sig op, og det lykkedes kun at overvinde dem ved hjælp fra det danske konsulat.

Rejsens triste oplevelser havde gjort hans sind endnu tungere og mere indesluttet. Men trods sygdom og nedbrudte nerver undte han sig ingen hvile. Han ville arbejde for sin kone og otte børns skyld, men måtte bukke under.

I de sidste timer før Apuschkin døde, ønskede han at tale med alle dem, han mente at have forurettet under indflydelse af sygdommen, for at de skulle tilgive ham. Et udslag af kærlighed og retfærdsfølelse. Han blev grebet af gudsfrygt, så han i de sidste minutter bad til Gud på sit modersmål, som han ellers aldrig benyttede.

Kisten stod udenfor, med mange skønne kranse, bl.a. en med meget stort bånd »von deinen Schwiegereltern«. Efter salmen »Så tag mig da ved hånden « blev kisten af naboer båret til vognen, og nu kørte ligtoget ad kirkevejen over Vrågård til Burkal kirke.

Her tog pastor Schwarz imod ved lågen, og under dansk salmesang gik man til graven, hvor Schwarz foretog jordpåkastelsen, på dansk. Derefter takkede redaktør og typograf Christian Lageri (dansk, gift med en søster til fru Apuschkin) på familiens vegne. Han talte smukt om den afdøde, der som en fremmed havde været loyal borger, og nu hvilede i den danske jord.

Pastor Schwarz bad alle følge med ind i kirken, i Guds hus. Dengang var kirkedøren for smal til, at en kiste kunne komme igennem. Også pastor Nielsen deltog $\mathrm{i}$ højtideligheden $\mathrm{i}$ kirken. Man begyndte med at synge "Jesus, meine Zuversicht«, dernæst talte pastor Schwarz på tysk. Det blev en meget lang og kraftig tale, ikke fri for fagter. Om afdødes tunge lod, mens han levede. Man så, at han var en fremmed. Udseendet, sproget og hans sæder og skikke røbede det. Men: det rigtige fædreland ville han finde $\mathrm{i}$ himlen, hvor han ville mødes engang med kone og børn, hvis de søgte til Gud. Han bad Gud stå dem bi og lede dem på den vej, der fører til dette møde.

Pludselig bad Schwarz, på dansk, menigheden synge første vers af "Klokken slår«, og så ville han fortsætte på dansk, da han kunne se, at der var mange til stede, der ikke kunne tysk. Så fortsattes på dansk. Vi sang: "So nimm denn meine Hände«, pastor Schwarz lyste velsignelsen på tysk. Til sidst endnu en tysk salme og Fadervor på dansk. 


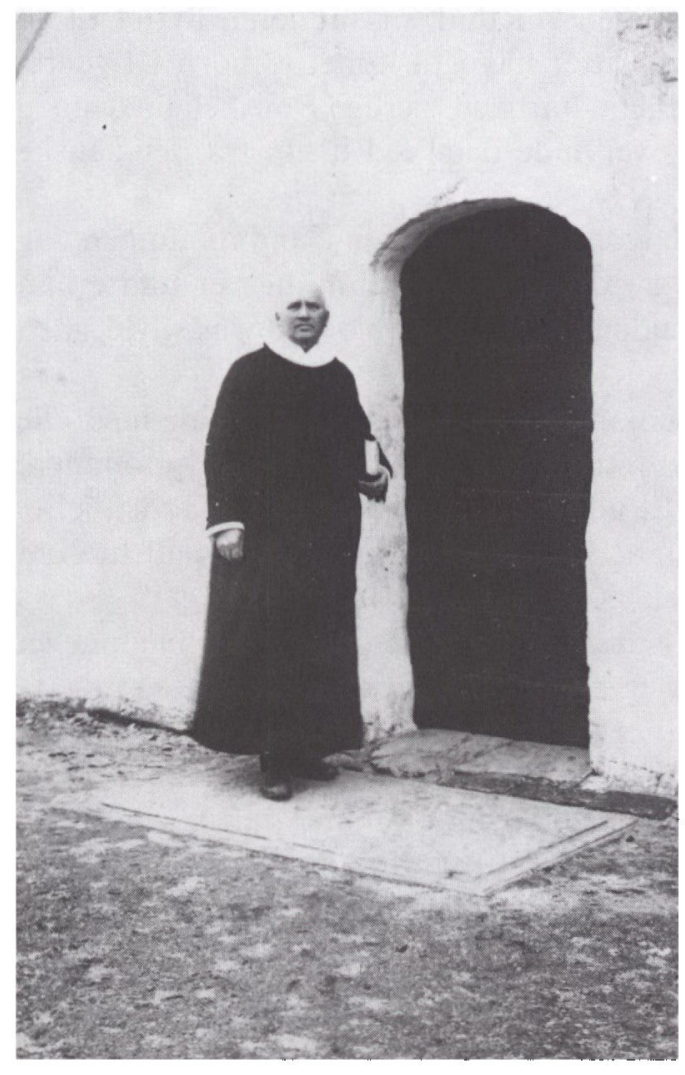

Peter Martin Christian Schwarz (1872-1945) startede sin prastegerning 1906-16 i Kliplev, hvorfra han flyttede til Burkal. Schwarz var holstener, praget af tysk dndsliv og den nordslesvigske indre mission. I 1920 valgte sognet med stort stemmeflertal at beholde Schwarz som sogneprast. I sin kirkelige og nationale holdning stod Schwarz langt fra Anna Rud Bentholm og mange danske i sognet. Men hans onske om at vare prast for hele sognet uden hensyn til nationale skel kunne ingen tage fejl af. (Foto ca. 1930, privateje)

\section{Pastor Schwarz}

Som nævnt var hjemmedåb det hyppigste. Vor fodermester Frans Block skulle en sommer have deres mindste barn døbt. Og ved samme lejlighed endnu et barn; det havde de ikke fảet gjort, inden de flyttede hertil. Vi ville gerne gøre det så festligt for dem som muligt og havde tilbudt familien Block, at barnedåben kunne foregå herovre $i$ vor havestue. Der var pyntet med blomster og grønt og levende lys.

Pastor Schwarz havde sagt, at han kom nok ved aftenstide. Det var det dejligste vejr. Alt var så kønt $i$ den stille sommeraften. Men vi ventede og ventede. Endelig kl. ca. $9 \frac{1}{2}$ kom præsten kørende i fuld fart ind $\mathrm{i}$ gården. Han skyndte sig ind. "Goddag, goddag, god aften, god aften. Kære! jeg skulle jo først til et møde i Lydersholm. Men nu kommer jeg! « Efter at have fået præstekjolen på: »Hvor er barnet? hvor er barnet? og hvor er vandet?« Han for omkring. Så blev de to 
børn døbt. Det tog ikke så lang tid. Efter at vi alle havde fået aftenkaffe, var klokken 11, da præsten kørte.

Blocks havde barnedåb en gang til. Den foregik hjemme i deres stue, dengang kun lille, så der var ikke megen plads, tilmed var der dækket kaffebord. Axel og jeg deltog i højtideligheden. Dåben tog ikke lang tid, men det var alligevel så kønt. Anna Block havde rakt et fad vand til pastor Schwarz, der stod ved et lille bord. Anne Block opdagede, da barnet havde fået vand over hovedet, at hun havde glemt et håndklæde til præsten. Hun rejste sig for at tage et i en skuffe. »Nej, nej, kære fru Block! Lad være med det. Jeg klarer mig fint selv.« Så tog han sit lommetørklæde op af lommen, rystede det lidt og tørrede sin hånd deri. Pastor Schwarz sluttede med en bøn og Fadervor. Han havde lige sagt Amen, og mens han satte sig på en stol ved siden af Axel, fortsatte han næsten i samme åndedrag: "Hvordan går det med roerne, hr. Bentholm?«

Pastor Schwarz følte sig ganske bogstaveligt som sjælesørger for hele sit udstrakte Burkal sogn, der strækker sig 16-17 km langs grænsen fra det yderste Store Jyndevad til Holmgård og Vindtved $i$ vest.

Præsten var værge for Georg Tychsen, der var født i Nolde 1912. Moderen var ugift. Georg var i 1937 fodermester på Grøngård. Den første tid han var gift og daglejer her, boede han 1-2 km fra Grøngård helt ude på Fredenshåb hos Th. Thomsen i den sydvestlige del af Lydersholm. Georg blev gift med vor kokkepige, Tinne Wrang fra Broballe på Als. Vi holdt bryllupsfrokost for dem på Grøngård. Nu skulle de have et lille barn døbt. En sommerdag i 1937 ved $3 \frac{1}{2}$ tiden holdt pastor Schwarz med sin bil på vejen lige øst for Grøngård. Han steg ud og gav sig til at skifte fra tysk til dansk præstekjole. Pludselig får han øje på Tinne, der står i vejkanten ved indgangen til deres lille hus, der ligger i Grøngårds have. Samtidig med at Schwarz knapper sin præstekjole, går han hen mod hende og siger: »Hvem er De?« Han fortsætter undskyldende: "Ja, jeg er ved at skifte præstekjole. Jeg har lige været henne at døbe et tysk barn, og nu skal jeg hen at døbe et dansk barn. Derfor skifter jeg nu fra tysk til dansk præstekjole. Men hvordan kommer De her? Hvad vil De her?«

"Jeg er Tinne Tychsen, Georgs kone. Jeg står her for at møde for køerne, at de ikke render ind i haven, når Georg kommer med dem«, siger Tinne. "Er I da bleven fodermesterfolk hos Bentholm på Grøngård? « »Ja, vi bor herinde $\mathrm{i}$ huset, lige inde $\mathrm{i}$ haven«. Præsten spørger forundret: »Jamen, bor I da her? Og hvorlænge har I da boet her?« »Siden 1. april«. 
Helt forfærdet råber pastor Schwarz: »Siden 1. april ... og jeg! som har bedt for jer ude hos Thomas'es«.

Få dage efter kom forklaringen på præstens udbrud. Han fortalte nemlig ved et møde en aften i skolen bl.a., at han havde inddelt sognet i 7 distrikter. Hver dag i ugen bad han for et distrikt. Han mente, at han ikke kunne bede grundigt nok for hele sognet på én gang. "Jeg beder for alle. Jeg beder for hver eneste familie i sognet. For Lydersholms vedkommende begynder jeg ude på Vindtved, og jeg nævner hver beboer med navn, så på Fredenshåb, enhver især i Grøngård og Lydersholm, ender på Østergård.« Mandag: Jyndevad. Tirsdag: Rens. Onsdag: Burkal. Torsdag: Bylderup-Bov. Fredag: Stemmild-Bov. Lørdag: Lydersholm-Grøngård. Søndag: Lund og Kværnholt. Og nu var der altså sket det, at Georgs uden videre var flyttet fra Fredenshåb til Grøngård, uden at præsten havde fået det at vide.

Der er ingen tvivl om, at han mente alt såre godt og gjorde det så godt, han kunne; vi følte bare, at hele hans måde var så fremmed for os. Han talte højlydt og kraftigt, så dæmpede han stemmen; ofte havde han mange fagter. Det forstyrrede ro og andagt.

Da Chr. Christensen, Lydersholm, blev begravet, samledes følget forst ved hjemmet. Kisten stod udenfor. Pastor Schwarz talte. Han fortalte om at tro, om hvordan vi skulle være for at komme $i$ himlen. Altsammen så rigtigt! Han sluttede med at slå hånden ned på kisten og sige: "Denne mand her, ved vi, hvor går hen!«

Efter at Schwarz var gået af, flyttede han til Sønderborg. Nogen tid efter døde Hans Hansen, Burkal. Han havde i mange år boet nabo til præstegården, og enken fik bud efter pastor Schwarz om at komme og begrave sin gamle nabo. Efter at have sluttet ligtalen i kirken, sagde Schwarz: "Kære, jeg takker mange gange, for at I har sendt bud efter mig, jeres gamle sognepræst. Det skal I bare gøre igen! Jeg vil meget gerne komme, kan I tro, og jeg skal med glæde begrave jer alle!«

\section{Dansk og tysk i skolekommissionen}

Eduard Petersen, Lille Grøngård, fortæller om et skolekommissionsvalg umiddelbart efter afstemningen 1920:

Amtmand grev Schack sendte en skrivelse til kommuneforstanderen for Grøngård kommune, Eduard Petersen, om at sørge for at få valgt en skolekommission på 5 medlemmer for Lydersholm skoledistrikt. Eduard Petersen skulle som den ældste af de to kommuneforstandere sørge for at få det $\mathrm{i}$ orden snarest. Eduard Petersen (dansk) henvendte sig til kommuneforstanderen i Lydersholm, Chr. Christiansen (tysk), 
og siger: »Hør, Christiansen, $æ$ har en skrivels fra $æ$ amtmand, te vi ska ha en skolkommission wåll«.

»Ja, det har æå făt«, siger Christiansen.

Dengang var alle landmændene i Lydersholm tyske. Al jorden dér var på tyske hænder, og der boede ingen gendarmer. Eduard Petersens tanke var at få det ordnet sådan, at danskerne alligevel fik tre og tyskerne to mand $\mathrm{i}$ kommissionen.

Petersen siger: "No tøs æ, te vi i Grøngård kommune skal ha tre, da vi hær det støst areal og hær betal mest to $æ$ skol'klass, og I to i Lysholm«.

"Ja, det tøs æ å ku væ rett«, siger Christiansen, »og wenn still do op i Grøngård kommun?«

»Ja, æ hæ tænt mæ sjell«.

"Nå, det er godt«, siger så Christiansen.

"Og så Lorents Hansen å Blomsgård «, fortsætter Petersen.

"Og så den trirre«, spør Christiansen.

"Så slår æ Iver Petersen, Majborg, for«, siger Petersen.

»Nej, itt Iver, han er så fortugen dansk, ham vil vi ett ha. Så da møj heller Thomas«, siger Christiansen.

"Wenn slår do så for, Christiansen, for Lysholm«, spørger Petersen. »Mæ sjell«.

»De æ godt, og wenn så mie?«, spørger Petersen.

"Nis Hansen«.

»Nå, de va jo godt! Så hæ vi e kandidate opstil'«.

No ska vi jo ha mindst fem stillere til underskrift, indtil 15 , og så skul' de bekjendtgøres $i$ begge kommuner, og wenn der inden en bestemt tid inne ny kandidatlist blyve opstild, så tørs de inne wål ha. De kam inte mee!

Så skrøv vi te æamtsrå om di fem mand. Så wa vi no egentlig færre (færdige).

Ved det næste møde sagde Christiansen og Nis Hansen (tyskerne): »Uha, wo va vi domm! uha wo blev vi snøtt! vi ku ha fâwn tre, og di anne kun to, men no er'et for sild «.

Så kam de en skrivels fra æamtsrå, te de sku væles en formand. En køn sommerdaw lo vi 5 ue o æ grønning ve æ skol, så bløw vi jens om å leg dær og væl æ formand. $Æ$ skul led'e, som den ældst' for talte Edv. P. videre.

Så si'e æ til Nis: »Wenn stemme do å, Nis?«

» $\mathbb{E}$ stemme å Lorents«, siger Nis. 
"Æ kan itt ha'et, æ kan itt ha mæ'et å gøje«, sagde Lorents.

Så si'e æ: "Wenn stemme do så å Lorents?«

"Stemme å dæu, sie Lorents.

Så si'e æ te Thomas: «Wenn stemme do å, Thomas?»

"E stemme å dæu.

"No hæ vi begge făt hver to stemmer, Lorents og mæu. Åll fie håd gi'en æ stemm a.

Eduard P. si'e te Lorents: »No stemme æå dæ, så æ do vål som formand $\ll$.

"Så va vi ve æend, æ så' et ti Christian bagefter: Wo kam de a, do og Nis vild' ha Lorents ti formand?«

"Jow«, si'e Chr. "Nis si'e, vi ska ham vål, for han er itt så stram dansker som Eduard Petersen! $\lll$

Tyskerne kunne have fået langt de fleste stemmer, hvis de var gået til valg.

Det blev aftalt i skolekommissionen, at der skulle undervises på tysk i 10 timer ugentlig, for at oprettelse af en tysk privatskole kunne undgås.

\section{Den skjulte kejser}

I Lydersholm skole hang der ved genforeningen 1920 to store billeder, et af kejser Wilhelm og et af Luther. I 1920 fik skolen et nyt stort uindrammet billede af kong Christian 10. Skolekommissionens formand Lorents Hansen var meget sparsommelig. Han mente nok, at man kunne bruge rammen om kejserens billede, så man sparede at købe en ny. Sådan blev det bestemt. En håndværker $\mathrm{i}$ byen, Georg Hansen, søn af den tidligere tyske lærer, skulle sætte kongen i ramme, og jo da sætte pap bagpå.

Engang i 1937 ville lærer Leick fjerne nogle fluer, der var kommet inden for glasset. Og hvad så han? Lige nøjagtig bag billedet af kong Christian sad kejseren, så man skulle tro, at han ventede på, og var parat til, at træde frem, når kong Christian trak sig nordpå igen!

\section{Den tyske privatskole}

Formanden for Foredragsforeningen, Axel Bentholm, skrev 23. marts 1939 til formanden for Nordsjællands fadderskab for Burkal sydsogn, gartner Holbeck, Birkerød, om den tyske privatskole i Lydersholm:

»I den sidste halve snes år er der rundt om i Sønderjylland oprettet mange tyske privatskoler. De ligger spredt over hele landsdelen; så er 


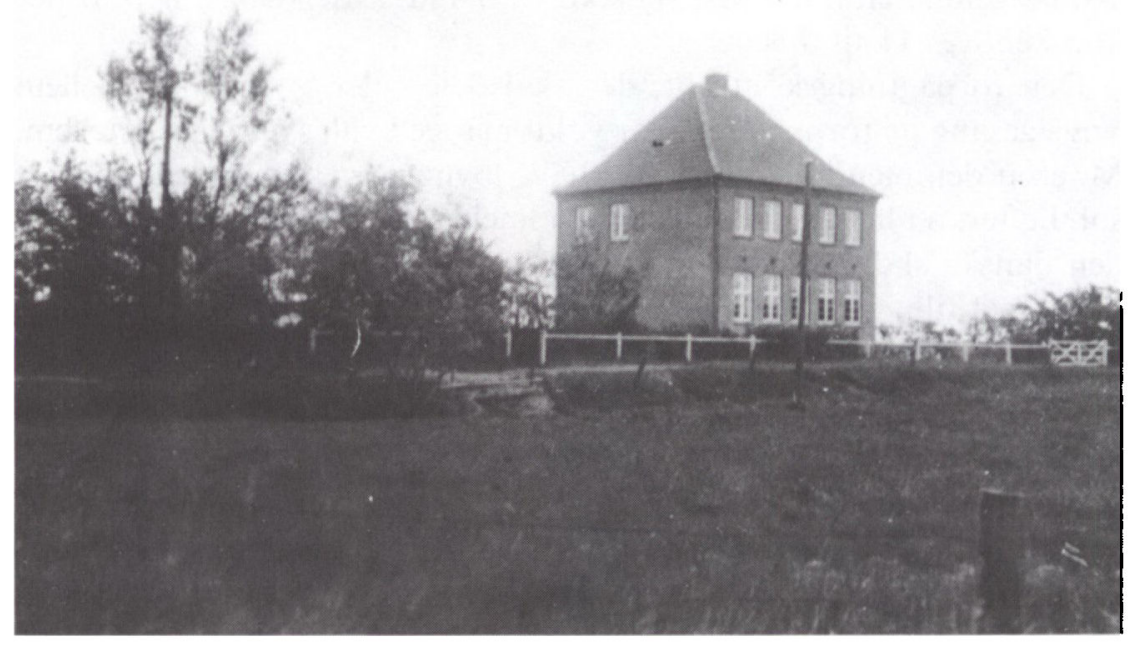

Den tyske privatskole i Lydersholm, opfort 1929. (Historiske Samlinger for Sonderjylland)

der adgang til, at alle børn fra tysksindede hjem kan få undervisning på tysk, enten i omtalte privatskoler eller i tyske kommuneskoler.

Indtil 1929 var der i Lydersholm skoledistrikt fælles skolegang for alle børnene i den danske kommuneskole. Her blev der givet tysk undervisning i 10 timer ugentlig. De daværende 8 tysksindede familier havde hidtil været tilfredse med de 10 tyske timer. Nu kunne de ikke nøjes med det. De skulle nu have deres egen skole, og den blev opført i sommeren 1929. En mand ville ikke have sine børn i den tyske privatskole. Hans to børn blev ved at gå i den danske skole. Som følge heraf måtte de 10 ugentlige tysktimer bibeholdes!

Med børnetallet $\mathrm{i}$ den tyske skole har det hidtil været småt. Det har jævnligt knebet med at nå de 10 elever året rundt, der er forudsætning for statstilskuddet $\mathrm{i}$ henhold til den danske friskolelov. 10,8 årselever har vist været det højeste tal, man har nået. For to år siden så det helt galt ud, for da var afgangen særlig stor, og tilgangen kun lille, så holdet ville gå ned på 6-7 børn. Den tyske lærerinde havde en overgang et plejebarn.

Men takket være Vogelgesangs jordpolitik var der mulighed for at opføre en ny landejendom, ja to, af Østergaards jorder. Og der blev 
hertil skaffet en forpagter M. fra Hejsager. M. er født i Ukraine, søn af tysk-østpreussiske forældre. Han har den gode egenskab at være familieoverhoved for en polsk kone og 11 børn, hvoraf de 5 var skolesøgende. Han har vist sig som en mand af den slags, hvoraf der kun behøves 11 til dusinet.

Den forpagtningskontrakt, der skal dele sol og vind lige mellem Vogelgesang og forpagteren, har voldt mange kvaler parterne imellem. M. er af den mening, at han skal have lovlig meget af vind og for lidt sol. I efteråret havde han sine børn udmeldt af privatskolen og tilmeldt den danske skole. I sidste øjeblik blev der givet køb, så omdelingen blev taget tilbage.

Men nu er situationen alvorlig igen! $M$. truer igen, og efter alt at dømme bliver børnene taget ud nu til påske. Det vil være et slemt slag for den tyske privatskole, for så er der kun 6 børn igen, og ikke nogen særlig forøgelse i udsigt. Med mindre den nuværende genstridige forpagter bliver sat ud og erstattet med en anden, mere føjelig og mindst lige så børnerig. Så meget er vist: for $\mathrm{M}$. er situationen meget alvorlig. Det er hans eksistens om at gøre. Hvis han gennemfører sit forehavende, må han regnes til de ualmindelige og kan betegnes som en »dagens helt«.«

\section{Lydersholm skole}

Vore børn kom i skole i Lydersholm hos larer Willy Leick. Inden vi forlod Århusegnen, havde vi jo talt en del om, at vi skulle helt ned til grænsen, helt ned til Tønderegnen at bo. En morgen, Svend skulle $i$ skole, ville jeg lige se efter, at han nu også var vasket helt ren. "Ork, mor, vi behøver da ikke være så moderne helt hernede!«

I en landsbys liv er landsbyskolen den kulturelle faktor. Skolebygningen købtes egentlig i 1821; det var gården Petersholm, der blev indrettet til skole. I 1883 blev den bygget om af en bygmester fra Sæd. Senere blev den udvidet, så der var plads til 40 børn. Efterhånden voksede børnetallet til 50 .

Lærer Leick kom her til Lydersholm skole i 1920. Man må sige, at der stilledes store krav til en lærer, hvor der er flere årgange i en klasse. Leick gik helt og fuldt ind for den skoleform, og han er en knag til opgaven, med en evne til at fortælle, så børnene lytter.

Noget ganske specielt for ham er hans store interesse for hjemstavnsundervisning. Han tog børnene med på cykelture, f.eks. til Burkal kirke, en tur langs grænsen, gård- og marknavne, fuglereder hjemme, hvad vi så i Grøngård skov, Lydersholm i oldtiden. Bagefter 
skrev børnene så stile om, hvad de havde set. I 1934 besøgte børnene Grøngård og skulle skrive om gårdens historie og dens beliggenhed; de skulle tegne bygningerne og lave et rids af markernes inddeling, fortælle om arbejdet, besætningen, avlen og driften i det hele taget, høsten. Ja, udgravningen af det gamle Grøngård slot begyndtes 1946 af lærer Leick som en praktisk form for hjemstavsundervisning.

Der er og har altid været en god kontakt mellem vor skole og vore hjem. Der blev holdt forældremøder, »eksamen « og en årlig julefest $\mathrm{i}$ skolen. I 1931 byggedes en ny forskole, der begyndte med 26 børn, og der blev ansat en lærerinde, Sophie Frandsen.

Julefesten var årets højdepunkt, og der var travle forberedelser en hel måned forud. Læreren sørgede altid for, at hvert eneste barn kom til at medvirke, i nissekomedie, til at fremsige juledigte eller prolog eller juleevangeliet, spille med $\mathrm{i}$ sketch osv. Til sidst blev det store juletræ tændt. Julefesten holdtes altid før jul, en dejlig fest, som alle var glade ved.

Prolog til skolens juletræsfest 1943. Af E. G.

Fire gange stod rugen på rod, og vinter skifted med vår,

fra dengang Krigens stormflod stod ind imod Danmarks gård.

Fire gange stod bøgen brud og talte sit lyse sprog, men vi synger stadig vor kvide ud under fremmede magters åg.

Fire gange vor julefest vi fejred', mens klokkerne løde, og i norden suser stadig en blæst, som pisker os næsten til døde.

Og dog er vi ikke af Gud forladt. Han kommer iblandt os så gerne; thi midt $\mathrm{i}$ krigens bælgmørke nat der tænder han julens stjerne.

Vi har kaldt jer sammen fra fjern og nær de små såvel som de store, 
og ønsker jer alle »velkommen vær« Vi håber, vi kan jer more.

Thi dansken er ikke skabt til tvang ejheller til sorg og tynge.

Lad derfor os følge vort hjertes trang og glæde os sammen - og synge.

Synge om julens dybe fred, der til os med Jesus kom, og om vor danske samhørigheds velsignede evangelium.

Sad skole

I vor naboby Sæd var der lige til 1945 tysk flertal. Her begyndte den danske skole efter genforeningen med 7 børn, $i$ en lille privat stue hos en gårdmand. Efterhånden som grænsegendarmernes børn voksede til, måtte man rykke op i "piselen « = storstuen. En ny smuk skole blev bygget af staten, ikke af kommunen, og blev indviet den 30 . september 1933. Ved den højtidelige indvielse var amtmand, grev Schack, landstingsmand Hans Jefsen Christensen og amtsskolekonsulent Nicolai Svendsen til stede. Vi var også med. Skolekommissionen havde tysk flertal og dens formand holdt sin tale på tysk. Man samledes bagefter i den tyske grænsekro til kaffe og taler. Her holdt lærer Højmark Jensen en flammende tale om Kristen Kold, hans skoletanker og frie syn. I sin undervisning følger Højmark disse spor.

En dag i krigens tid lagde Højmark mærke til, at nogle af drengene sad og fumlede med noget under skolebordene. Det viste sig, at drengene rullede små cigaretter af hjemmeavlet tobak. Højmark tog det $\mathrm{i}$ stiv arm: "Op på bordene med tobakken, så skal jeg vise jer, hvordan I skal bære jer ad!« $\mathrm{Da}$ alle var færdige med at rulle cigaretter, råbte han: „Så tænder vi!»

\section{Foreningsliv. Forsamlingshus}

Da vi kom her til egnen i 1928, var beboerne tysksindede på de fleste gårde $\mathrm{i}$ Lydersholm. Der var mange gendarmboliger med små haver omkring. Straks i 1920 bosattes der ikke mindre end et par og fyrre gendarmer i Lydersholm, og til disse blev der bygget træbarakker. 20 grænsegendarmer bevogtede dengang, efter tur, grænsen på strækningen fra Vindtved til Flyvsholm. Tyske og danske kunne $i$ de første 
10 år efter genforeningen leve fredeligt mellem hinanden og komme sammen. De allerfleste talte dansk, også hjemmetyskerne. Resultatet kunne blive pudsigt, når der blev blandet tyske brokker ind.

"Ich bin så scheiss in stand og $\mathfrak{x}$ er slet it rigte opgeregt eno; $\mathfrak{x}$ har slett int fån mi morgenkaffe ino«.

"Uha, ich bin så scheiss in stand til morgen «.

En bonde på Holmgård sagde: "Habe ich dir nicht so oft gesagt, at do itt må komm så møj schmør o $æ$ brø巛.

"Guten Tag! ... høj, det fåldt nok ner«.

Lederen af tysk ringridning i Saksborg kommanderer: "Still gestand! Rectsum! og så li'e ind a e lejgaff «.

Hørt ved de »danske« nazisters aftenmarcher: „Linksum«! (den pågældende gør forkert) »Ved du ikke, hvad »linksum« er? Linksum er venstre om! «Nå ja, så ved jeg det«.

Da der i 1929 blev oprettet en tysk privatskole, blev det mindre hyppigt at danske og tyske kom sammen. Endnu sommeren 1930-31 holdt både tyske og danske unge fælles sanglege på en mark i Lydersholm. På stille aftener kunne vi høre sangen her på Grøngård. Til begravelser fortsatte alle også med at komme sammen. Men når det gjaldt folkelige møder, samledes dansksindede og tysksindede herefter hver for sig.

"Selskabelig forening" blev stiftet 28 . oktober 1925 med 40 medlemmer i Lydersholm skole. Lærer Leick blev formand, overgendarm Th. Andersen blev næstformand, landmand Hans Ravn, Bejers kro, kasserer, overgendarmerne C. Mathiesen og E. Petersen blev festarrangører. Sammenkomsterne blev afholdt i skolen eller i private hjem. Den første foredragsaften var 19. november 1925. Der var mødt 36, og biskop Vilhelm Balslev fra Ribe holdt et kirkeligt foredrag.

I 1927 virkede foreningen ikke; men 21. oktober 1928 ønskede man at komme i gang igen. En kreds af interesserede medlemmer samledes hos overgendarm Frandsen. Ved andele à $10 \mathrm{kr}$. var samlet $210 \mathrm{kr}$., og det blev besluttet at købe en barak af grænsegendarmeriet. Den stod ved vejen fra Lydersholm til Bejers kro og skulle koste $600 \mathrm{kr}$. Sprogforeningen ville give et tilskud på $500 \mathrm{kr}$. Barakken blev gjort $3 \mathrm{~m}$ længere, skillevæggene blev taget ned, og "Selskabelig forening " rådede nu over et til forholdene svarende lokale. "Lydersholm forsamlingshus« blev indviet den 16. december 1928 med overgendarm Frandsen som formand. Det var dagen efter, at vi første gang var på Grøngård. Der var ualmindelig stor tilslutning både fra Lydersholm by og fra Jejsing og Rens. Det begyndte kl. 3 om eftermiddagen med taler af 
"Danmarks mindste forsamlingshus" $i$ Lydersholm. (Historiske Samlinger for Sonderjylland)

fhv. minister H. P. Hanssen og gartner Jepsen fra Bylderup. Om aftenen læste lærer Chr. Demuth fra Ravsted et Blicher- og Aakjær-program. Der blev sunget kraftigt, og stemningen var god og hyggelig.

Den 3. januar 1929 holdtes juletræsfest, 3. februar skydning, 10. februar afstemningsfest. Pastor Janus Knudsen, Bylderup, fortalte om en rejse til Letland. Trods megen sne og ualmindelig hård frost var mødet godt besøgt. Ved kaffebordet taler, sang og god national stemning. Det var første gang, Axel og jeg var i Lydersholm forsamlingshus, en stor oplevelse for os begge. Utallige er de gange, vi kom der siden!

Forsamlingshuset var jo meget lille. Ved et bestyrelsesmøde ca. 1931 blev det vedtaget, at bordene skulle blive inde i huset. De måtte ikke smides ud, med mindre der var en særlig grund dertil, og så skulle husets formand spørges.

Ved sammenkomsterne i forsamlingshuset synger vi, hører foredrag eller oplæsning og hygger os ved kaffen. Her blev lyttet med opmærksomhed og sunget med hjertevarme og kraft. Her er et fællesskab, hvor alle kender alle. Snakken går ved kaffebordet uden kunstpauser, mens tobaksrøgen lægger sig tæt om forsamlingen og øger hyggen i petroleumslampernes eller lysenes skær.

I vor lille træbarak lever vi alle med i det nationale og kulturelle liv, der har til huse her. Alle de dansksindede møder trofast op til mange dejlige og rige aftener. Vi føler barakken som en storstue i en bonde- 
gård. Unge og ældre kommer til stede og morer sig sammen, som er vi én stor familie. Vi vil aldrig glemme det!

Vi holder hvert år et adventsmøde i december, julefest for de voksne tredje juledag og for børnene femte juledag. Julefesten plejer at være den bedste af vore sammenkomster. På bordene står små juletræer. Når julelysene er tændt, er her den allerbedste julestemning, man kan tænke sig. Voksne børn her fra byen og egnen, der er kommet hjem på julebesøg, deltager altid. Ved julefesten mødes de med hele egnens befolkning, og så bliver de så rart sønderjyske igen i sprog og væsen. En formand, Carlsen, sagde engang i sin velkomsttale på sit sønderjyske mål, at »det er da så ra at se de gamle hoveder igen«.

Når der var julefest for de voksne $\mathrm{i}$ forsamlingshuset, medbragte alle selv kaffebrød. Det var praktisk, for det var jo ikke let at vide, hvor mange der kom, og vi husmødre havde alligevel bagt til julen. Ind over bordene byttede vi med hinanden, brune kager blev vekslet med klejner fra et andet køkken, lettere vaniljekranse med tungere julekage osv. Hvidklædte syngende skolepiger fra landsbyen gik langsomt Lucia-optog med lys rundt i salen. Til slut stillede de sig oppe på scenen og fuldendte sangen, mens vi alle rejste os op i stille glæde. Ja, det var hyggeligt, stilfærdigt og kønt, så fjernt fra nutidsmekanikken. Da blev der jul i sindene, og vi ligesom løftedes op over hverdagen.

I årene deromkring spillede Nørgaard fra Solvang i Thy (fru Vestergaards far). Han var en af vore allerbedste rigtige gamle spillemænd og mestrede violinen til fuldkommenhed.

Den 22. juni holdt foreningen Sct. Hansfest på Grøngård med god tilslutning.

Det var morsomt, når e gammel smej, smed Mathiesen, filede løs på sin hjemmelavede "Teufels-Geige«. Eller når Andreas Edlefsen, Hovmose, spillede på sin harmonika, der ikke var fri for at være utæt hist og her. Vi nød det alle, når Andreas Edlefsen sang solo »Det var en lørdag aften« og »Det var en daw i høstens tid, da Pær slow row for fuld « af Karsten Thomsen, på en særlig melodi. Ja, jeg kunne blive ved at høre harmonikaens toner længe efter at være kommet hjem.

I 1920 var gendarmerne kommet til den nye grænse den 10 . maj, og $i$ en årrække holdtes 10 . maj fester til minde herom. Gendarmerne dannede deres eget hornorkester. Der var altid stor interesse for skydning; tit og ofte var der skyttefester.

I marts 1931 var der foredrag og oplæsning af min far, redaktør Bertel Jensen, Aarhus Amtstidende, om den fynske bondedigter Mads Hansen. 
Forsamlingshuset går i ateren

Min broder Harald Rud var o. 1932 blevet pressechef ved radioen; han tilbragte ofte sine ferier her på Grøngård. Han holdt meget af at færdes i grænseegnen, fiske i åen og tale med den stedlige befolkning. Han fulgtes med gendarmerne på deres lange gåture ad stierne langs grænsen og deltog i møder i forsamlingshuset.

I en lang årrække havde der været en stille overenskomst mellem den danske og den tyske radio om at medvirke til afspænding i grænseegnene ved at undgå det nationalt prægede $i$ udsendelserne. Men da nazisterne kom til magten, var det slut med grænsefreden $i$ den tyske radio. Den danske radio havde derimod hidtil ladet den nationale spænding ved grænsen ret uomtalt. Harald Rud fik nu den tanke at prøve at lade sønderjyderne selv både synge og tale til lytterne. Han skriver 21. november 1933 til os på Grøngård:

"Ja, så igår har vi fået udsendelsen fastlagt. Det bliver fredag den 29. december kl. 9 aften, og varigheden bliver ca. $3 / 4$ time. Titlen bliver "En festaften i Danmarks mindste forsamlingshus«; men det er altså afhængig af, at I er parate til den nævnte aften at holde »fest «, dvs. holde en sammenkomst, som vi i forvejen må lægge programmet for, hvad de 3 kvarter angår.

Jeg har tænkt følgende: jeg indleder med en reportage uden for på vejen, ligegyldigt hvordan vejret er. Det bliver en skildring af egnen ved grænsen, Tønder osv. Imens må vi tænke os, at aftenen er igang derinde, så foredraget tænkes afsluttet; vi kommer så ind under sangen, efter foredraget. Sangen kan være $» V i$ vestjyder ...॥ eller »Jeg elsker de grønne lunde« uden musik.

Imens jeg fortæller lidt om huset indvendig, kan kaffebordet dækkes færdig, og så må ordstyreren give ordet til oplæseren, gerne Claus Eskildsen i sønderjysk mundart; muligvis en lille tale om grænsen lige før oplæsningen. Landstingsmand Jefsen Christensen, som jeg talte med om det forleden, foreslog gartner Jepsen, Bylderup, som både var en af de gamle fra fremmedherredømmets tid og som kunne holde en meget munter tale. Vil du ikke undersøge det?

Så skal vi have sunget "Det var en daw i høstens ti'«. Skriv igen, om der er andre typisk sønderjyske sange, I gerne vil synge. Helene [Harald Ruds kone] minder om, at Højmark Jensen i Sæd engang sang en vise med linjen nog jeg har friet mig en Jyllands pige, det er det bedste, som jeg har gjort«. Kan I finde en eller anden fra egnen, der kan synge den? Og! Kan de den?

Skriv også et par andre sange ud over de almindelige, som er altfor 
kendte. (Jeg kunne af dem tænke mig "Jyden han er stærk og sejg" og eventuelt »I alle de riger og lande «). Hvordan er det med Rørdams, den med nog pælene ved grænsen, de står, men standser ej«? Det er ikke helt sikkert, vi skal synge dem, men jeg vil gerne høre, hvordan det ligger.

Og så må I have gendarm-orkestret (horn) i funktion den aften. De skal ikke spille meget i radio-udsendelsen; men de skal med i en enkelt sang til sidst. (Privat vil jeg fortælle dig, at jeg jo gerne i forbindelse med den musik, som lyder lidt stærkt, vil spørge om et gammelt klaver! Men dette må du ikke tale om!) Hvis gendarmerne kan spille f.eks. "I alle de riger og lande«, så er det nok til mig. Men det skal de også. Gendarmerne skal spille en sang! Det er betingelsen for, at I får 200 $\mathrm{kr}$. for forestillingen «.

Den 29. december 1933, femte juledag, var der juletræsfest med radiotransmission. Denne begivenhed var for os på Grøngård en af de helt store, men i foreningens protokol står der ikke ret meget: »juletræsfest for ældre og unge. Transmission, hvor Math. Christiansen og Eduard Petersen talte, Eskildsen læste, og musik af egne kræfter, flere sange; i det hele taget var det vellykket «.

Mange på egnen var ret skeptiske over for tanken om transmission. Det var første forsøg i sin art: direkte transmission fra den lille barak. På transmissionsdagen var der rykind på Grøngård hele dagen igennem. Her blev forløbet aftalt. Teknikerne ankom og begyndte at sætte nye telefontråde op, så der blev direkte forbindelse med København.

Det var et smukt julevejr. Sneen dækkede mark og eng. Det lille forsamlingshus lå malerisk med rødmalede trævægge i det hvide snelandskab. Harald Rud stod udenfor og fortalte om egnen her ved grænsen, at der netop var møde nu: toner fra "Jeg elsker de grønne lunde« lød ud til ham »om trængsel og nød dig fristed, jeg elsker dig dobbelt ømt « og »end er der en Gud foroven, som råder for Danmarks sagu.

Seminarielærer Claus Eskildsen, Tønder, var aftenens hovedtaler. Her var tale, sang og fortælling på sønderjysk folkemål. Carl Petersen fra Majborg sang visen "Jeg så i øster, jeg så i vester«.

Vi sad alle bænkede om det traditionelle sønderjyske kaffebord. Med sin rolige, dybe stemme sagde Rud i mikrofonen: "Stemning! Tro nu ikke, det er spiritus og andet, der giver denne herlige stemning, nej ... men det sønderjyske kaffebord! det har så afgjort betydning, jo-o, også nationalt set«.

Grænsegendarmernes hornorkester spillede udmærket. Det er jo 


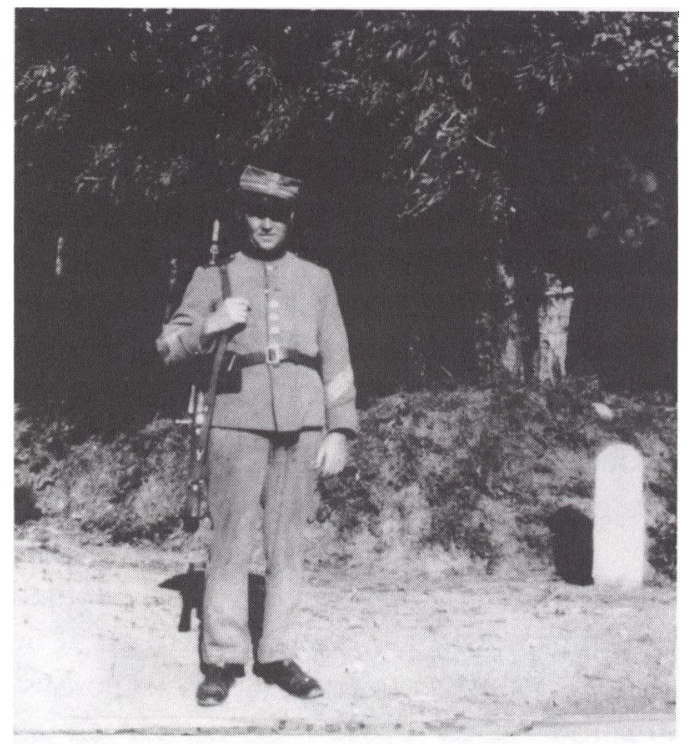

Gendarmerne satte deres prag på granseegnen ved Lydersholm $i$ årene efter genforeningen, og de var med til at skabe det danske foreningsliv. Overgendarm Frandsen, som blev formand for Lydersholm forsamlingshus $i$ 1928 , er her fotograferet på vagt ved Grongärd. (Foto $i$ Anna Rud Bentholms privatarkiv, Landsarkivet for de sonderjyske landsdele)

netop så morsomt, når vore egne gendarmer spiller. Musikken lyder kraftigt i det lille forsamlingshus, og mikrofonen er følsom. Det fik Rud til at sige: »Hvor kunne et klaver gøre godt«.

Transmissionen blev virkelig vellykket og hørtes i mange hjem, også $i$ andre egne af landet. Herom vidner de mange breve, der blev sendt til foreningens formand, til forsamlingshuset med stak for trofast grænsevagt «. I alt kom der over 25 breve og kort. Radioen fik et lille hundrede opringninger med tak.

Få dage efter transmissionen kom der et brev fra København med tilsagn om et klaver som gave fra fru Agnes Rathje, f. Mossin. Gennem fruens slægtning, general Albert Fabritius fik jeg en del oplysninger om fru Rathje. Hun var datter af en oberstløjtnant Mossin, der havde været kaptajn under krigen 1848-50. Vi skulle bare selv købe klaveret, hun betalte!

Lydersholm fik flere tilbud om klaverer. Såvidt vides kom der 7 klaverer til grænseegnen foranlediget af transmissionen.

Klaveret blev taget i brug første gang ved Sønderjysk Teaterforenings turné mandag den 15. januar 1934. Det var kunstmaler Struckmanns turné »Danske natur- og kulturværdier«. Frk. Irene Graae, Beate Novi og Edith Dam medvirkede. Huset var stuvende fuldt af folk, også 
rundt om fra. Pressefotografer havde meldt sig og blandt gæsterne var magister H. V. Clausen og amtslæge dr. Lausten Thomsen.

\section{Kongebesøg}

1. juni 1934 besøgte kong Christian 10. Lydersholm forsamlingshus. Dronning Alexandrine, kronprins Frederik, prins Knud og prinsesse Caroline Mathilde var med i kongens følge, ligeledes amtmand grev Schack og politimester Martensen-Larsen.

Skolerne gav børnene fri; alle børn fra den danske skole skulle naturligvis hen at hilse på det danske kongepar. Når børnene fra den tyske skole fik fri, var det muligvis for, at de ikke skulle møde kong Christian på vejen hjem fra skole.

Flagene vajede rundt omkring. En flagallé viste vej fra trekanten, hvor modtagelsen fandt sted, hen til forsamlingshuset. Vor sognerådsformand, Jørgen Tinglef, bød kongeparret med familie et hjerteligt velkommen; han citerede "for en fremmed barsk og fattigt er vort land, men rigt på minder.« Vor nabokone Hannchen Hansen, Ny Blomsgaard, havde i de sidste dage gået og tænkt meget over kongebesøget. Mens hun gik og "syslede« derhjemme havde hun skrevet et velkomstdigt, som blev fremsagt af Svend Bentholm:

»Vi elsker vor konge og dronning

vor kronprins og prinsepar.

Vi byder Dem velkommen,

en højtidsdag vi har.

Velkommen til vor landsby.

Vi lover dig ærlig vagt

ved grænsen imod sønden.

Vi kæmper uforsagt.

Om kampen tit til daglig

kan synes strid og hård på en dag som denne vi føler, at alting et solstrejf får.

Vi kæmper sejt som jyder.

Vi værge vil vort land.

Vi kæmper for vor konge

og for vort fædreland. 
Vi mødes små og store, og en inderlig bøn vi frembær:

at Gud vil velsigne Danmark

og vor konge i al hans færd!»

Gamle Eduard Petersen, Lille Grøngård, havde netop modtaget Ridderkorset få dage $\mathrm{i}$ forvejen og var mødt for at hilse på kongen og takke for korset: "Æ si'e mi kong så manne tak for e ko's« ... så gik han i stå, men fortsatte, idet han med fingeren pegede på grev Schack: "Ham dær, e amtmand, var jo ud' ve mæ mæ'et den anden daw《. "Det har De nok også fortjent«, sagde Christian 10. "Ja, de si'er di jo«, svarede Eduard Petersen.

Også Nissen Thomsen fra Ladelund syd for grænsen var mødt for at hilse på. Kongen spurgte om, hvordan de havde det derovre? Har I det ikke lidt meget, lovlig meget, med det her? og så rakte kong Christian sin højre arm rask i vejret ... »Hils derovre! « Nissen Thomsen var lykkelig; han sagde til alle dansksindede, han mødte: »Jeg skal hilse fra kong Christian!«

Danskheden organiseres efter 1933

Da genforeningen var fuldbyrdet i 1920, tænkte den danske befolkning nord for grænsen vel egentlig: nu er vi danske alle, og tog det med ro nationalt set. I 1933 kom så de tyske udfordringer i bladene og på møder i Flensborg og Ekernførde, hvor Flensborgs senere overborgmester dr. Sievers og pastor Peperkorn fra Fjolde ganske åbent og frit erklærede: "Den tid er ikke langt borte, da Nordslesvig igen er tysk $\ll$. Bølgeslaget af den nazistiske uro gik ind over Nordslesvig. Tyskernes kraftige agitation mærkedes overalt. Før verdenskrigen var Møgeltønder kendt som »det lille Danmark«. Her boede ingen tysksindede! Der blev prædiket på dansk. Nu i 1933 blev der oprettet en tysk privatskole.

Også i Rørkær arbejdedes der for tysk privatskole, skønt der kun boede to tyske familier med tre børn. Men så var der $\mathrm{i}$ anmarch en arbejdsmand med mange børn.

De såkaldte »danske nazister« var også i fuldt sving. De holdt øvelser og møder rundt omkring, rakte armen i vejret til hilsen. Navnet "danske nazister« kunne måske fange de blakkede. Men for os at se svarede navnet nu ikke til virkeligheden; det var fuldstændig tysk det hele. Vor bager i Bylderup Bov var meget ivrig »dansk nazist«; 
virkeligheden en stor, stor tysker: „Wir wollen nun slet int zu Deutschland«, sagde han.

$\mathrm{Nu}$ blev danskerne vågne, rundt omkring lød den ene protest efter den anden. I Tønder blev der afholdt et stort idrætsstævne 12. maj 1933. Her gik bl.a. 1400 børn i optog fra Tønder banegård gennem hele byen til sportspladsen. En rigtig dansk børnefest. Forrest red stolte ryttere, Bertel var en af dem. Her fra Grøngård kørte far og mor for deres børn ind til stævnet. Børnene havde alle tre hver sit lille danske flag $\mathrm{i}$ hånden. Da vi på hjemvejen kørte igennem Sæd, en ret tysk grænselandsby, gemte Bertel sit flag på vognens bund. "Hvorfor gør du det, Bertel?« Jeg synes ikke, vi må drille tyskerne«. »Ork «, sagde Svend, „det er da derfor, vi er langs idag«. Dette lille træk viser, at også børnene, 13 og 11 år, var klar over den nationale situation, hver på sin måde.

Det store stævne på Dybbøl den 11. juni vil vi huske. Også i grænseegnen blev der holdt en række nationale møder, bl.a. på Rens Efterskole. Her samledes om eftermiddagen mange indbudte mænd fra vor egn til fortrolig drøftelse af situationen, og om aftenen var der et offentligt møde.

I løbet af efteråret 1933 blev der oprettet Danske Samfund i 32 sogne her i den truede firkant. Danske Samfund for Burkal sogn blev oprettet den 28. oktober 1933 på Rens Efterskole. Axel og jeg var også derovre. Der gik lister rundt $i$ hele sognet, og der kom 680 underskrifter; det betød, at man meldte sig ind i Danske Samfund og selv skrev under på, at man regnede sig for dansksindet.

Afdelinger af Det unge Gransevarn blev oprettet 1933/34, først i hele Nordslesvig, siden landet over. Her langs grænsen blev det fremfor nogen Carla Schibler, der kom til at levendegøre Det unge Grænseværn. Som vandrelærerinde cyklede hun rundt vinter efter vinter, underviste og ledede gymnastik, sanglege, samariterkursus, håndarbejde og folkedans. Grænseværnets møder i det gamle land vakte stor interesse for grænseegnene. Mange unge landbrugsmedhjælpere og huslige unge piger nordfra kom hertil for at være med $\mathrm{i}$ og opleve vor tilværelse. Det varmede om hjertet, og man mindes hele denne store skare med taknemmelighed.

I maj 1936 oprettedes et nordsjællandsk fadderskab for Burkal sydsogn (Rens, Jyndevad og Lydersholm). Formand var gartner Holbeck, Birkerød. Hvert år har fadderskabet sendt pengebeløb til støtte for det danske arbejde, og vi er dem stor tak skyldige for forståelse og hjælp. 
I forbindelse med fadderskabet kom der mange interessante besøg her på Grøngård, ofte i flere dage, bl.a. gartner Holbeck, arkivar Hans Ellekilde i Dansk Folkemindesamling, rektor Haderup fra Bagsværd, lektor Brøndsted, hofjægermester de Neergaard, Førslev, der var formand for Tolvmandsforeningernes fadderskab for Burkal Nordsogn. Efter 1945 har Nordsjællands fadderskab også opgaver i Ladelund og Medelby syd for grænsen.

\section{Folkedans}

Dansene er reelle ytringsformer for sund og frisk livsglæde, har ikke overlevet sig selv, men er naturlige for os, som de var det for tidligere slægtled. Fra alle egne af landet er de gamle danse og deres melodier samlet ind og trykt $i$ folkedanshæfter hver fra sin egn.

Da Carla Schibler ville til at tage fat med folkedans også her i Lydersholm 1934-35, kom hun pludselig en dag cyklende her til Grøngård for at tale med Axel som formand for foredragsforeningen. Hun kom frem med sit ærinde og spurgte, om hun måtte begynde at lede folkedans i vort lille forsamlingshus den og den aften. "Tja«, sagde formanden, „det kan De jo godt få lov til, men jeg danser nu ikke selv med, ikke tale om! «

Schibler tænkte, at formanden måske alligevel var en ældre mand. Hun så på de hvide hår, som han faktisk havde haft de sidste 15 år dengang, og svarede, at det forstod hun så godt, og det gjorde heller ikke noget, når bare han kom til stede! Folkedanseaftenen kom. Der var mødt mange. Også Axel Bentholm. Om det var demonstrativt ment eller ikke, tør man knap nok sige, eller tænke, men han havde sine lange ridestøvler på. Så skete det, der faktisk fik uendelig stor betydning for alle os: Axel lod sig rive med, dansede med. Det varede ikke længe, inden han smed frakken og lagde piben. Nu var gnisten tændt! Siden den aften gik han med, deltog i alle folkedanse-aftener her, ja, oven $i$ købet i stæuner og folkedanse-ture til Fyn og Sydslesvig. Han blev vel nok den allerivrigste.

Carla Schibler nød, i det stille, sejren. I begyndelsen var det Nørgaard, Solvang, der spillede violin til; men ellers var det undertegnede, der sad ved klaveret, aften efter aften $\mathrm{i}$ mange år. $\mathrm{Nu}$ blev det sådan, at når vi havde bal, enten i Lydersholm, eller f.eks. i Landboforeningen, var Axel ivrig danser, også moderne dans. Han smed først frakke, dernæst slips, det kunne vel hænde også vesten, men så heller ikke mere! Han var i hvert fald den sidste, der gik, når dansen var slut. 
Vandrelarerinde Carla Schibler (I895-1965). (Historiske Samlinger for Senderjylland).

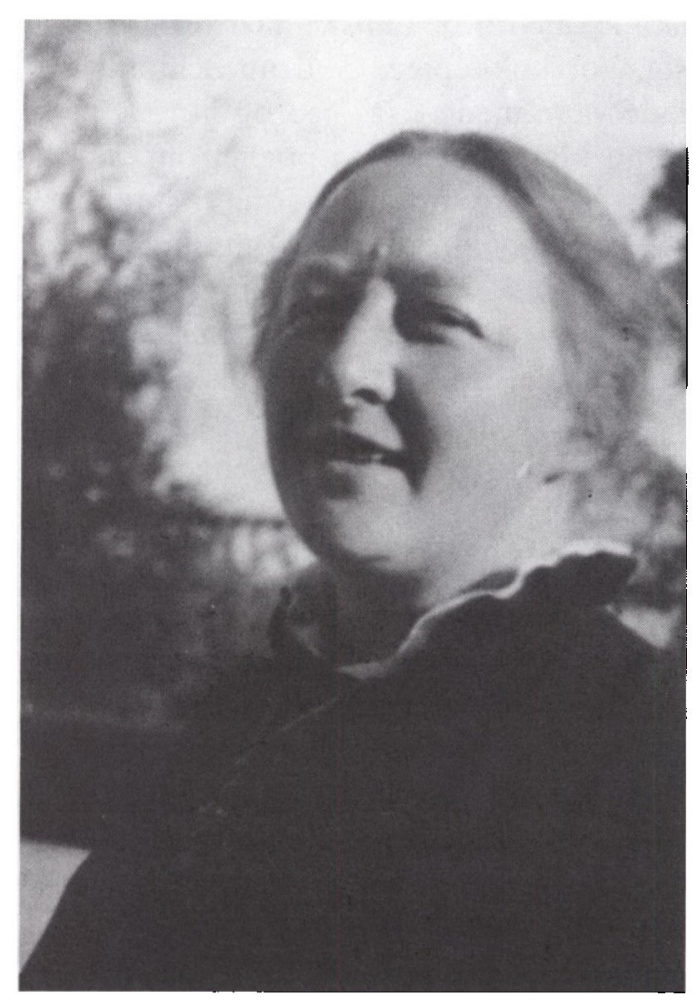

Selv ved "ungdomsdagen« i Landbo- og husholdningsforeningen mødte Axel op. Hvis han ikke skulle med, hvem skulle så? Han fulgte foredragene med største interesse, deltog også i drøftelsen bagefter. Han sørgede for, at Carla Schibler kom 3-4 gange og gav undervisning $i$ vals. For børn om eftermiddagen og for voksne om aftenen. Der var god tilslutning, 40 deltagere, og man var glade for det.

Dilettantspil havde vi også stor glæde af. Dilettant er en af de grene i foreningsarbejdet, der samler flest folk til huse. Alle skal hen at se, høre og more sig, når deres egen familie eller bekendte optræder. Her i Lydersholm har der faktisk været dilettant omtrent hver vinter.

\section{Foredrag}

I 1938 var man blevet enige om at prøve at afholde forskellige politiske aftener. Der skulle være én taler fra ét parti hver aften. Frits Clausen 
skulle tale for de danske nazister. Han havde 25-30 meningsfæller med sig. Vor kokkepige, Gudrun Schmidt fra Kollund, og jeg kunne ikke lade være med at ta' ned og høre. Bager K. fra Bylderup Bov havde jo nu i lang tid talt og præket om den danske nationalsocialisme. $\mathrm{Nu}$ kom han så, "giraffen«, som vi skulle se.

Han begyndte roligt, komplimenterede Lydersholm med det storsind, at ville lukke forsamlingshuset op for ham. Nu stod han her $\mathrm{i}$ det lille berømte forsamlingshus, som vi alle kender af omtale ... Ved kaffebordet skulle der være diskussion. Begyndelsen var rolig. Clausen begyndte med at sige, at man kunne se af billederne på væggen, hvad folk var: »i et dansk hjem hænger kong Christian, i et tysk ...« Mathias Christiansen afbryder: »hænger Hitler«. Nu blev Clausen gal, følte sig truffen: »Ja, jeg har Hitler hængende hjemme, ikke fordi jeg er tysk, for det er jeg ikke! heller ikke hele min slægt! Vi er danske! Men: fordi jeg respekterer denne mand! Luther har jeg også! Har ikke også mange andre danske det? Jeg bliver vred, når nogen påstår, at jeg er tysk. Jeg bliver rasende! og hvis De vover at sige det blot én gang til, vanker der en ørefigen $=$ klø. Har De forstået mig? ikke herinde, men udenfor! En lussing! forstår De?« Hans Korsgaard forsvarede Det unge grænseværn, Marcussen osv.

Axel Bentholm sagde som formand: »Jeg må på det dybeste beklage, at dr. Clausen så fuldstændig har forglemt sig selv, misbruger gæstfriheden. Vi er skuffede, vi beklager, det skulle ske. Vi er blevet fornærmet på det dybeste. De må huske, dr. Clausen, hvor De er! Nemlig i vort forsamlingshus, til et almindeligt oplysningsforedrag om DNSAP, i lighed med oplysningsforedrag om andre partier på en anden aften. Vi er ikke i en kro til politisk rabaldermøde.

Og De, bager $\mathrm{K}$. havde lovet os et sagligt møde. Så ville vi gerne komme og høre«. Bageren var her til kaffetid og førte en voldsom diskussion.

Axel påpegede for bageren det uheldige og dumme $\mathrm{i}$, at han som leder

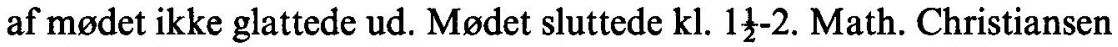
sagde, at han kunne nok forstå, at Marcussen og Claus Eskildsen ikke vil mødes med Frits Clausen, når den står på klø! Så fik vi prøvet det.

En anden aften talte redaktør Lageri fra Haderslev for arbejdernes grænseorganisation. Det var naturligvis både sagligt og roligt. Der var kun 14 deltagere.

I årenes løb har der været mange, mange udmærkede foredragsholdere, med overordentlig interessante, alsidige emner. Her nævnes kun en del: 
Lektor Egeberg Jensen, Tønder: Forholdet mellem tysk og dansk i dag

Seminarielærer Claus Eskildsen, Tønder: Slægter og slægtsforskning. - Folke- og statsgrænser, med lysbilleder, 2 aftener. - Geopolitik, blod og jord, grænselære.

Lektor Kondrup, Tønder: Københavns belejring 1659.

Amtslæge Lausten Thomsen: Tonder amts fortid: munkene i Logumkloster, stormfloden 1634, guldhornene.

Rektor Jakob Randrup, Tønder: Forskel mellem nationerne.

Adjunkt Jørgen Andersen, Tønder: Henrik Pontoppidan Lykke-Per, 2 aftener. Lidelsens problem. Lidelsen er sjælens rette element. (Noget svar at få fat $\mathrm{i}$, sagde Axel Bentholm). Henrik Pontoppidan Det forjættede Land, 2 aftener. (Folk var meget glade for at høre fremstillingen, sagde A.B.)

Adjunkt Jorgen Andersen samt seminarielarer Asmind Graugaard: Den jyske hede i ord og toner. Fuldt hus med megen begejstring.

Pastor N. P. Nielsen, Højer: Høststemninger ved høstgilde. Stillingen ved grænsen i dag samt mange gode adventsmøder.

Pastor Ebbesen, Døstrup: Køllerpolitikken. Niels W. Gade, hans tonedigtning og betydning for dansk musikliv. Ebbesen sang nogle af Gades sange og laste morsomme fortællinger.

Provst Schülein, Løgumkloster: Børn ser på dig.

Magister Rahr, Tønder: H. C. Andersen.

Frederik Vestergaard, "Solvang«: Juleskikke i gamle dage.

Forstander Tormod Jørgensen, Høng: Samarbejdets betydning.

Højskolelærer Bo Rud, Askov: Frihed i dansk belysning + personlig frihed.

Overportør Alfred Kristensen, Bylderup-Bov: Danske i grænsesognene.

Skuespiller Texiere: H. C. Andersens eventyr.

Lærer Niels Kjems, Sydslesvig: Ophold i Belgien som krigsfange.

Forstander Hans Lund, Rødding: Liberalismen.

Forfatteren Hans Rosenberg: New Zealand med lysbilleder.

Faktor Lageri, Haderslev, redaktor for Grænse-Posten: De sønderjyske arbejderes grænseorganisation. Mandolin-orkestret fra Flensborg spillede.

Forstander Trier Hansen, Abild: Jul på en gård et sted.

Gårdejer P. J. Gad, Hejsel, maler Ferslev, Døstrup og lokomotivfører Andersen, Tønder: Oplæsning.

Hansigne Lorenzen, Ballum: Oplæsning.

Erik Appel, Ellehus: Skolemøde.

Pastor Knudsen, Bylderup: Letland og Polen - 2 gange.

Skuespiller Albert Luther.

Larer Chr. Demuth og Mette Demuth, Ravsted: Ypperlig oplæsning, flere gange.

Realskolelærer Detlef og frue, Ålborg: Den danske bonde i ord og toner.

Forstander Morten Bredsdorff, Tender.

Vestergaard, "Solvang«, indleder diskussion: Ungdommens fritid.

Adjunkt Jørgen Hatting, København: Trøjborg.

Skolebestyrer Haderup og frue, Bagsværd, var her på fadderskabets vegne for at sætte sig ind $\mathrm{i}$ forholdene $\mathrm{i}$ den sydlige del af Burkal sogn.

Lærer P. Marcussen skulle gøre rede for Det unge Grænseværns navneforandring til Dansk-nordisk Ungdomsforbund. "Foredraget var godt, men meget vidtløftigt og svævende, « siger A. B. Høstede en del kritik for forandringen.

Lærer Højmark Jensen, Sæd, flere gange. 
Mads Madsen, Karup ved Ribe: "Den jyske hedebonde og folkesange " Aakjær og Anton Berntsen. Mads Madsen er 60 år, står daglig i tørvemosen, laver. selv daglig 4000 tørv. Cyklede herned! Næste morgen kl. 5 herfra til Ribe, hjem til sine tørv.

Pastor Nielsen, Aagaard.

Direktør Thomas P. Hejle, danserinden Irene Graa, skuespilleren Kaj Holm.

Lektor Kaj Sieverts, Tønder: Er der noget ved at være dansk?

Lærer Larsen, Emmerlev, lærer Damborg Nielsen, Jyndevad.

Lærer Jensen, Majborg, tidligere Solderup: Island.

Tage Albertsen: Drejø.

Carla Schibler: De kvindelige arbejdslejre.

Gæster fra Ladelund, Vestre, Karlum: Sydslesvig-aften.

Laust Kenholt: Germansk ret - romersk ret.

Peter Malberg og Ellen Malberg: Oplasning.

Kaptajn Bartholdy: Den niende april - fuldt hus!

Pastor Høgel, Burkal: Nationalitet og kristendom. Samme aften spillede violinisten Niels Nielsen ypperligt, akkompagneret af fru adjunkt Andersen, Tønder.

Adjunkt Otto Høyer, Tønder: En foredragsrakke om tiden fra 1870 til i dag, 5 gange. Meget interessant, men besøget for ringe, siger A. B.

Oberstløjtnant Skjoldager: De danske frivillige i den finske vinterkrig.

Forbindelsesofficer, oberst H. M. Lunding, Flensborg (1947).

Redaktør Rütting, Kbh.: Bag jemtæppet i den tyske østzone. Tyskland af i dag.

Rektor Feilberg Jørgensen, Tønder: Sønderjyllands historie.

Adjunkt Knud Fanø: Sønderjyllands historie i tiden 1864-1920.

Lærer Leick: Vor hjemstavn.

Pastor Høgel: Kirke og stat.

Pressechef v. radioen Harald Rud: Småskildringer.

Redaktør Bertel Jensen, "Århus amtstidende«: Den fynske bondedigter Mads Hansen.

Lærer Christiansen, Jejsing: Oldtidsbebyggelse i Sønderjylland.

Politimester Vagn Bro: Et liv i rettens skranke.

Redaktør John Danstrup: Den udenrigske situation.

Sognerådsformand Jørgen Tingleff: Kommunalpolitik, sognerådet arbejder.

Svend Rud Bentholm: En rejse og ophold i Østen, som apoteker på Borneo i 3 år og på Java i 3 år, foredrag og lysbilleder.

Udflugt 1932 til Husum, Frederiksstad, Slesvig og Flensborg, 23 deltagere, meget vellykket!

Ejnar Federspiel, København: Foredrag med oplæsning.

Forstander Hans Haarder, Rønshoved.

Larer Christiansen, Tinglev.

Larer H. Nederby, Hjordkær.

Larer Thomsen, Brøns.

Konsulent Buchreitz, Ribe.

Højskolelærer Juul Andersen, Askov: Udenrigspolitik.

Overlærer Ruge, Flensborg: Det ny Palæstina, Finland i film.

Larerinde, frk. Schrøder, Aventoft: Afstemningstale.

Ved adventsmøder: Pastor Bork Hansen, Løgumkloster, pastor Mogens Barfod, Højer, pastor Lund, Bylderup, forstander Hans Bogh, Højer ungdomssk.

Konsulent Aalling: Høsttale, senere film fra Holland og Belgien.

Karl Dall, Kongsbjerg: En tur i Vestslesvig, lysbilleder og foredrag. 
I 1935 og 1936 kom Heimdalstudenternes turné; de spillede, sang og læste digte, fortalte om foreningens arbejde for Nord- og Sydslesvig.

Blandt Heimdal-studenterne i 1936 var også cand. jur. Axel Riishøj. Han boede på Grøngård. I 1957 var Axel Riishøj som Ribe stiftskasserer medvirkende ved Burkal menighedsråds køb af Grøngård.

6 studentersangere fra København var på turné i grænseegnene 26. juni til 1. juli 1936. Engang spillede "Sønderjydsk Symfoniorkester " (den halvprivate forløber for Sønderjyllands Symfoniorkester) i Lydersholm. Programmet begyndte med klassisk musik og sluttede med champagnegaloppen. Foreningens formand takkede: »I begyndelsen kneb det jo lidt, men til sidst viste de da, at de ku' spill'".

\section{Friluftsteater}

I en lang årrække (1936-37 til 1956) har vi her på egnen kunnet glæde os over friluftsteatret $\mathrm{i}$ Lille Tønde skov. En dejlig sommeraften hvert år fik vi den rige oplevelse at se og høre gode danske skuespillere opføre gode teaterstykker. Forskellige turneer spillede her. Gennem mange år kom Odense Teater.

Skuespillerne blev indkvarteret på egnen. Også her på Grøngård har vi $\mathrm{i}$ alle årene haft nogle, gerne to ad gangen. De kom ved middagstid den ene dag og kørte igen kl. 10 den næste dag. Det var morsomme, interessante og livlige besøg, mange gode samtaler, så det ofte blev sent, inden vi kom til ro.

\section{Danmark besat april 1940}

Den 8. april 1940 var der møde i Lydersholm forsamlingshus. Seminarielærer Claus Eskildsen, Tønder, talte om geopolitik: hvordan nogle geopolitikere mente, at et stort land havde ret til at tage et lille land, når det var nødvendigt for dets "Lebensraum« osv.

Inden mødet begyndte gik rygtet fra mand til mand, at alle bilejere i Lydersholm havde fået ordre til at holde deres biler parate! til hvad? Eskildsen begyndte: »Englænderne har lagt miner ved Norges kyster! og hvad betydning, det kan få for os, er ikke godt at vide « ... og han fortsatte om geopolitik og Lebensraum, viste lysbilleder bl.a. om beliggenheden af danske stednavnetyper i Sydslesvig.

Der blev uro i salen. Det blev meddelt, at der forelå bud om, at alle gendarmer skulle nordpå kl. 12. Alle pårørende tog hjem straks. Husbond tog også hjem, for at være på Grøngård om noget skulle ske.

Claus Eskildsen viste os på kortet, at Danmark faktisk ligger som en pikkelhue over Tyskland. "Jeg tror ikke, de kommer! sagde han og slog sig med hånden på hovedet og gentog: "De kommer ikke!« 
Mødet blev fortsat. Gårdejer Mathias Christiansen, der da i to år var formand for foredragsforeningen, udtalte meget bevæget: "Når grænsegendarmerne skal væk, kommer der sikkert militær herned til grænsen. Ellers føler vi os da forladt. Hvad der end sker, så vil vi holde sammen om det danske." Alle var dybt bevægede, og vi sang "Altid frejdig « ... med tårer i øjnene, med ængstelige tanker for hvad der nu ville komme.

Straks vi kom udenfor, fløj en flyvemaskine lige over hovedet på os. Vi var spændt på, hvad natten ville bringe; gendarmerne gik hele natten med deres familier frem og tilbage på vejen i Lydersholm. Til sidst gik de hjem, ventede i spænding. K1. 3 næste morgen kom der kontraordre: gendarmerne skulle blive hjemme.

Kl. $4 \frac{1}{2}-5$ morgen drønede de første store tunge mørke flyvemaskiner lavt hen over gården, over egnen. Det føltes, som havde store flager af Tyskland revet sig løs. Fra Grøngård så vi ikke andet end flyvemaskiner og atter flyvemaskiner. De formørkede næsten himlen, fordi de fløj så lavt. De store træer omkring gården svajede for lufttrykket. Storken i reden på taget af den store lade stod rolig, tilsyneladende ganske uberørt. Vi for alle ud og skulle se de mange flyvemaskiner. Dog Svend var rolig og fattet som altid. Han blev liggende $i$ sengen lidt endnu, indtil han måtte op og cykle til skole i Tønder. Ja, den dag måtte han cykle uden om de mange endeløse kolonner af fremmede soldater, der færdedes på landevejen.

I det fjerne hørtes rummelen fra landevejens stenbro - landevejen fra Rødebæk til Tønder var dengang chaussé-brolagt. Der gik en stadig strøm af militær i endeløse rækker. Men dog kun i det fjerne. Vi følte ingen trang til at vise interesse for de ubudne gæster, der så fuldstændig brød ikke-angrebspagten.

Vi lyttede til radioen. Der måtte da komme noget vigtigt nyt. Morgengymnastik som vanligt? Vi lyttede stadig! Ved kl. $8 \frac{1}{2}-9$ lød en fremmed stemme: "Hallo! Hallo! Vi gør taleøvelser! Vi gør ta-le-ø-velser!« Dette blev gentaget flere gange. Udtrykket »gør« er tydeligt nok oversættelse fra »machen«. Vi var klar over, at nu var der sket noget, der gjorde den danske radio anderledes.

Hjemmetyskernes holdning var ikke til at tage fejl af. "Das haven die Dänen gut von «, råbte en gårdejerkone i Lydersholm, højt over til en tysk nabokone. I Tønder delte hjemmetyskerne chokolade, cigaretter og bolsjer ud til de tyske soldater, mens de gik gennem byen. Ja, de mødte med flere spande vand og kopper til at drikke af. En købmand delte ud af sine varer $\mathrm{i}$ lange baner. Svend kom hjem fra skole og 
fortalte, at Hecht (= nazisterne) hejste hagekorsflaget på statsskolens flagstang, mens der blev sunget morgensang. Hagekorsflaget blev også hejst på seminariet, på Tønder rådhus og fra kirketårnet.

Om eftermiddagen den 9. april var sognerådsformanden i Udbjerg og en gårdejer $i$ Tønder. Sammen med et par andre hjemmetyskere fejrede de invasionen på adskillige restaurationer. Hen under aften gik de stærkt beduggede op gennem Tønder hovedgade. Gårdejeren var så vidt, at han ikke mere kunne se, men nok høre. Gårdejer Mathias Jepsen, Rørkær, passerede parret og sagde: "Go Avten«. Gårdejeren spurgte: »Hvem var det?« hvortil sognerådsformanden svarede: »Det var da Mathias fra Rørkær«. Den anden slog fast: "Ja, han er jo go' nok! Han kan få lov at bli' her, men alle de andre Jyllandsdanskere, de skal Fanden gale mig herut!

\section{Hjemmetyskerne og de fremmede}

Men livet skulle jo gå videre, trods alt, ja netop: trods alt! Det gjorde et stærkt indtryk på os alle, at kong Christian 10. allerede den 11. april red sin daglige tur gennem hovedstaden, rank og tryg. Det gjorde, at byen blev sig selv bevidst igen! Ved sin ranke holdning viste kongen, at Danmark ikke var et kuet land.

I vort kære lille forsamlingshus i Lydersholm boede 14 tyske soldater i godt 3 uger. De sov $i$ halm. De gik vagt ved grænsen i følge med de danske gendarmer, én tysk soldat og én gendarm.

Vore hjemmetyskere gjorde alt for de tyske soldater, bagte og bragte alt godt til dem. Med en vis harme og sorg i sindet hørte vi den 20. april: "Nu fejrer hjemmetyskerne Hitlers fødselsdag i forsamlingshuset, i vort danske forsamlingshus! « Ganske rigtigt: de tysksindede koner kom spadserende gennem byen til forsamlingshuset, bærende, højt, den ene lagkage efter den anden. "No ska vi hen i e forsamlingshus«, sagde de triumferende. Man skulle jo mene, at det havde været mere naturligt at holde festen i den tyske privatskole. Et øjenvidne beretter, at de tyske soldater drak kaffen og nærmest åd lagkagerne ... og var så mætte, at de lod sig dumpe ned i halmen og sov! Hjemmetyskerne havde anstrengt sig meget for at tækkes soldaterne. De havde indbudt dem til varm aftensmad $i$ hjemmene osv. Men soldaterne sagde nej tak ..., og så måtte hjemmetyskerne selv komme til soldaterne. Soldaterne har selv udtalt, at de undrede sig over hjemmetyskernes holdning over for Danmark og danskerne. Hjemmetyskerne havde det jo så godt her i Danmark; ja, soldaterne var trætte af at høre på deres klager. „De 
skulle bare prøve at komme til Tyskland; de ville betakke sig for de forhold derovre. Her i Danmark har I så stor en snut (og viste med fingrene, hvor højt de kunne gabe), ovre i Tyskland vil I få så lille en snut « (og så kneb de munden sammen).

Hjemmetyskerne jublede for hver fremgang de tyske hære havde. I Lydersholm flagedes med hagekorsflaget, da Paris blev taget. Det var der mange hjemmetyskere der gjorde, hele Nordslesvig over.

De tænkte vel som en gårdejer i Jejsing, som sagde til husbond her: »Kampen føres ingenlunde for at undertrykke andre nationer, men for at bibringe dem fremgang og lykke ved hjælp af den tyske kraft! Målet er at bringe orden og ro overalt i Europa. England er den egentlige undertrykker og skal knuses!«

\section{Dagbogsnotater fra besattelsesårene}

Den følgende spændende tid kan jeg vist bedst fastholde ved at indflette mine dagbogsnotater $\mathrm{i}$ beretningen.

Maj 1940: Redaktør Viggo Lausten, Vestslesvigs Tidende, Tønder, arresteres af Gestapo midt om natten. En måned efter lyder budskabet: Redaktøren har begået selvmord i Vestre Fængsel på grund af de overvældende mange indicier imod ham. Anklagen lød på spionage (man mener: vist næppe helt ubegrundet). Vi deltog i begravelsen. Pastor Magle i Tønder holdt en personligt præget og stærk tale.

Dr. Ejnar Dahl, Tønder, arresteres. Blev frigivet en måned efter.

Der kom nye flagstænger ved hver tysk ejendom. Hidtil kunne man altid med sikkerhed hævde, at hvor der var flagstang, bor der en dansker.

Midten af juni 1940 lød rygter: "Nu skal Nordslesvig indlemmes i Tyskland! Det skulle ske den 28. juni, dagen for undertegnelsen af Versaillestraktaten i 1919. Om formiddagen skulle kong Christian tale i radioen og tage afsked med Sønderjylland. Om eftermiddagen skulle Hitler byde velkommen ... fra Versailles. Men dagen før bekendtgjordes i Nordschleswigsche Zeitung, at al demonstration aflystes. Det var en stor skuffelse for hjemmetyskerne. En vagtmester i Udbjerg stod i sin have og hørte en samtale mellem sognerådsformanden og en gårdejer: »Det er alligevel mit livs største skuffelse, at vi ikke måtte få lov til at hejse det tyske flag i går«, hed det.

Købmand Axel Michelsen og politimester Brix arresteres.

Legitimationskort indføres og kræves!

Længe før krigen var en udstrakt spionage grundigt gennemført. Alt 
hvad der blev sagt ... særligt ... blev opnoteret af hjemmetyskerne og indberettet til Åbenrå. Man vidste det, man ved det, af udtalelser fra hjemmetyskerne selv!

Den 11. juli 1942. Der faldt engelske bomber i Tønder. En engelsk flyvemaskine ville ramme et tog med soldater på banegården. I stedet ramtes et stort hus, herved dræbtes dyrlæge Jensen og datteren Inge, samt fru lærer Larsen og hendes datter Birte.

Den 28. september 1942. 400 brandbomber faldt om natten over Rørkær. 2 huse knustes fuldstændig; vognmand Höeg, hans datter Mathilde og fru Höegs gamle far blev dræbt. Otto og Kirsten Frederiksens gård brændte. I skæret fra den brændende gård forsøgte alle Rørkærs beboere at redde dem i det sammenstyrtede hus. Alle hjalp, hvor de kunne. Der blev så oprettet et nattevægterkorps, der trådte $\mathrm{i}$ funktion under luftalarm.

Bagermester Svend Petersen, redaktør Berntsen, fotograf Buchard og kaptajn Dichmann, alle fra Tønder, arresteret.

December 1942. Lektor Aage Rosenkjær, Tønder (en meget afholdt lærer) arresteret.

Den 29. august 1943, den dag glemmes aldrig. Læge Dahl, Claus Eskildsen arresteredes igen, tillige provst Schülein, Løgumkloster. Uniformer og våben blev taget fra det danske militær, mandskabet blev interneret. Regeringen nedlagde hvervet, rigsdagen lod sig hjemsende.

Pludselig optrådte Heimwehr, et frivilligt korps af vore hjemmetyskere, i uniform og med gule armbind. Fra Tønder $150 \mathrm{i}$ alt, flere fra Jejsing og Rørkær. De stod vagt ved broer og veje, i og ved Tønder. Heimwehr forlangte at se legitimationskort; morsomt nok, men nederdrægtigt også over for gamle naboer, som de så udmærket kendte.

Da Heimwehr begyndte, blev der sat et skarpt skel. At tænke sig! Ens naboer og også handlende skulle - og ville! - bære våben mod os ... våbenløse!

December 1943. Forpagter Mathiesen Hansen, Hestholm, bliver arresteret og ført til Koldinghus, frigivet $1 \frac{1}{2}$ måned efter.

Lektor Rosenkjær til Vestre Fængsel, Frøslev, Tyskland!

Forpagter Mathiesen Hansen arresteres igen, frigives $1 \frac{1}{2}$ måned efter ... igen.

Redaktør H. H. Bernsen og godsekspeditør Gjerlev, Tønder, arresteres, samt købmand Aksel Michelsen, politimester Brix, politimester Martensen-Larsen og søn (sønnen indtil man fik fat i faderen). Gjerlev fri $\frac{1}{2}$ år efter. Kaptajn Bartholdy og lærer Marcussen arresteres!

Sommeren 1944. Lærer Leick, Lydersholm, modtog trusselsbreve. 
Det medførte nervechock. På rekreation $\frac{1}{2}$ år. Spændingen vokser $\mathrm{i}$ forholdet til hjemmetyskerne. Usikkerheden breder sig; det føles som er der stikkere rundt omkring, alle vegne.

Den 26. maj 1944. Helt chokerede blev vi da journalist Erik Vestergaard i telefonen meddelte os, at grænsegendarmeriets chef, oberst Paludan-Müller i samme stund førte en tapper ildkamp mod Gestapo i sit hjem i Gråsten.

Den 19. september 1944. Tyskerne arresterede det danske politi; $i$ Tønder blev ingen anholdt, mange forsvandt. Politimester Brix indkaldte til hemmeligt møde på Tønderhus.

Samme dag ringede grænsegendarmeriets fungerende chef, kaptajn A. S. Ørsted Petersen rundt til vagtmestrene og sagde: »Nu er De ikke i tjeneste mere; men hold Dem hjemme! De vil blive afhentet!« Dagen efter, $i$ middagsstunden, blev en lastbilfuld (en af de grågrønne tyske vogne med presenning over) lyseblå gendarmer læsset af her lige syd for Grøngård ved indkørslen. Det var gendarmerne fra Sæd. De skulle vente her ved grøftekanten, mens tyskerne hentede gendarmerne fra Lydersholm og Dyrhus. Vi gik alle derud. Arbejdet måtte hvile et par timer, det blev 3 . Vi skulle jo da sige farvel til vore gendarmer. To tyske soldater stod vagt, bevæbnede med håndgranater, maskinpistol og revolver.

Efter at alle Lydersholm-gendarmerne var hoppet ud af bilen her ved gården, kørte bilen til Udbjerg og Dyrhus efter flere. Imens sad vi på grøftekanten og snakkede med gendarmerne.

Kaptajn Ørsted Petersen lå på ryggen og med hænderne under nakken og hovedet i græsset og hvilede sig. Han var meget træt, han havde også kørt hele natten og hjulpet tyskerne med at hente gendarmerne. Det lyder utroligt: "Om en time kommer tyskerne og henter gendarmerne«. Sådan lød en telefonbesked fra kaptajn Ørsted Petersen til vagtmesteren. Vagtmester Andersen gik frem og tilbage ude på vejen og ventede. Gendarmerne gik og ventede på at blive afhentet. Mange, ja alle kunne være gået under jorden. I stedet blev de ført til internering i Frøslevlejren, og herfra blev en del senere ført til Tyskland.

I Jyndevad var nogle gendarmer ikke hjemme, da tyskerne kom for at hente dem. De cyklede så selv til Frøslev senere! Om natten kørte en lastbil i tågen mod en flok kreaturer ved Lille Tønde Kro. Vognen viste sig at være fuld af gendarmer, der skulle føres bort.

En lille solstrålefortælling. En gendarm i Jyndevad var blevet kaldt hjem fra marken, hvor han gik og pløjede. Da han kom hjem og ville 
ind af køkkendøren stod en tysk soldat vagt ved døren. Han sagde: "Hvad vil du her, se at komme væk«, og skubbede gendarmen ud. Sådan slap han for at komme med til Frøslev. Man sagde, at man ikke kunne finde ham.

Axel sagde til kaptajn Ørsted Petersen: »Det her går ellers fredeligt til!«. "Ja«, svarede kaptajnen. "Jeg har selv bedt om at måtte køre med rundt til hver enkelt gendarm, og anmode ham om at følge med; så ville der ikke ske noget, og så har tyskerne lovet, at vi alle må komme hjem om 8 dage«. »Tror De på det« svarede Axel.

Forrest kørte kaptajnen sammen med to tyske officerer ... i PaludanMüllers bil! Så kom en stor grå lastbil med presenning, og sidst en personbil. I chefens bil blev alle pistolerne lagt. I lastbilens bund alle geværer og patroner, som gendarmerne så måtte træde på.

14 dage efter kom overgendarmerne Peder Hansen og Chr. Pedersen hjem. De blev hentet på Jejsing station i jumbe af husmor på Grøngård. Peder Hansen beretter, at kaptajnens holdning gjorde det lettere for gendarmerne at følge med. Men i Frøslev viste de internerede danske officerer kaptajnen en kold skulder, ville ikke have med ham at gøre. Sådan fortælles der.

141 gendarmer førtes 5 . oktober til koncentrationslejren Neuengamme ved Hamborg og til andre lejre. Her fra Lydersholm: grænsevagtmester Alfred Høj (d. 13. januar 1945), overgendarm Jens Petersen (d. 29. november 1944), overgendarm Karl Larsen, gendarm Hans Skovmand, gendarmaspirant Kaj Adolf Nielsen (d. 22. januar 1945), aspiranterne Kr. Paulsen og Ole Holm samt Jensen.

Den 7. oktober 1944 arresteredes gårdejer Gotthardsen, Lund, og vogmand Hans Therkelsen, Bylderup Bov. Man beretter, at en yngre mand, antagelig stikker, nogle dage forud havde været rundt bl.a. hos Gotthardsen, for at sælge Kaj Munks erindringer. Manden havde rigtig forstået at tale med folk, og havde fået Gotthardsen til at fortælle alt for meget om ...

I hvert fald forsvandt gårdejer Svend Hansen ud af bagdøren, mens et par tyske herrer stod og talte med fru Mette »om de ikke havde noget halm at sælge?« Sognefoged Mathias Johannsen, Kværnholt og skomagermester Bøgen forsvandt "under jorden«. Bøgen spadserede en tur hen ad gaden i Bylderup Bov, da han blev advaret.

Efter dette arbejdede stikkerne igen med at sælge »erindringer «. De var bl.a. hos landmand Aksel Mathiesen, Nolde, snakkede og snakkede og kom til sidst ind på arrestationerne, spurgte ud om Svend Hansen osv. Jo, Gestapo foregav at ville købe halm eller hø! 
Den 17. oktober 1944 arresteres bankassistent Erik Svendsen, Tønder, isenkræmmer Holger Petersen og trafikkontrollør Alfred Nielsen, Tønder (den sidste kom fri kort efter). De holdtes en tid som fanger (under skarp bevogtning) i Alexandrineskolens kælder, når de ikke var "på arbejde«; det var at køre med i de forreste vogne $\mathrm{i}$ de tyske troppetog, som gidsler. En flok fanger gik gennem Tønder gade under skarp bevogtning, deriblandt Erik Svendsen, Holger Petersen, overlægen på Grindsted sygehus, gymnastikinspektør Braae Hansen, pastor Riishøjgaard fra Rise og flere.

Den 26. oktober $1944 \mathrm{kl} .5$ om morgenen arresteredes Svends studenterkammerat Anton Andresen, søn af landmåler Andresen. Han gik på seminariet. I første time kom Gestapo og undersøgte seminariet, fandt to maskinpistoler på loftet. En seminarist blev arresteret, en del forsvandt. Gestapo fandt en maskinpistol i seminariets tørv og yderligere to på loftet.

Da seminariet i 1943 genoptog arbejdet efter sommerferien, udtalte forstander Morten Bredsdorff over for eleverne, at enhver form for illegalt arbejde ikke ville blive tålt og medføre øjeblikkelig bortvisning.

Da Ortskommandanten i Tønder tryglede den danske politimester om at fortsætte $i$ hvert fald som luftværnschef, fik han som svar de allerede klassiske ord: "Ich bin aufgelöst, Herr Kommandant«.

I Tønder trængte to berusede tyske underofficerer ind på sygehuset, hvor de $\mathrm{i}$ en sygestue generede sengeliggende patienter.

Rygterne svirrer: nu har gendarmerne i Neuengamme plettyfus; 3 er døde. Overgendarm Schultz, Lydersholm, kommer hjem fra Frøslev. I alt er 61 gendarmer sendt hjem. Husmor kørte igen til stationen for at hente ham hjem.

November 1944: overbetjent A. H. Sørensen, Tønder, arresteredes, samt kontorist Kaj Petersen på Burkal kommunekontor. Gendarmkonerne lider meget; man forstår det, det er meget enerverende, at de intet ved om mandens skæbne. Måske bliver gendarmerne pint? sultet? fryser og er syge? måske uden lægehjælp og pleje?

Brødrene Tygesens forretning $\mathrm{i}$ Tønder ødelagt ved påsat brand.

For tredie gang reddes Tønderhus fra at komme $\mathrm{i}$ tyskernes hænder.

Den 1. december 1944 får vi at vide, at lektor Aage Rosenkjær er død 18. november i Husum og begravet dér sammen med 8 andre. Ens sind fyldes med sorg og harme.

Pastor Magle arresteret.

Den 7. december 1944 får vi meddelelse om, at overgendarm Jens Petersen, Lydersholm, er død i Neuengamme. Det greb os om hjertet. 
Det var den første fra Lydersholm, der bukkede under. Vi frygtede det værste; vi ved, at vore gendarmer er syge!

Den 12. december 1944. Er lige kommet hjem fra besøg hos nogle gendarmkoner i Lydersholm. Det var gribende at besøge Jens Petersens unge enke, dybt fortvivlet over sin mands død. Det, der trykker mest, er uvisheden om alt det, der er gået forud for døden. Hun sad med sin 1-årige søn på skødet, aldeles utrøstelig. Så besøgte jeg fru vagtmester Høj, hvis mand er i Tyskland. Trods sorg og ængstelse viser hun et enestående mod og styrke. Forleden havde de sølvbryllupsdag, så sagde hun: "Jeg har alligevel haft den lykke at leve sammen med min mand i 25 år. Det er værre for de unge, der lige har begyndt samlivet og har ventet sig så meget af fremtiden«. Fru Høj er rolig og ligevægtig.

Fru gendarm Larsen græmmer sig, er ligefrem syg af sorg og uvished og selvanklage. Larsen havde haft til hensigt at forsvinde, men hun bad ham lade være. Fru vagtmester Andersen skulle til Frøslev, og måtte tale med sin mand et kvarter.

En sandfærdig beretning fra Esbjerg (gennem skræddermester Skov, Tønder): Skov har en ven i Esbjerg. Denne ven havde en tysk oberst indkvarteret. Obersten måtte altid gennem familiens spisestue for at komme ind i sit værelse. Obersten var en tiltalende mand, og der havde ikke været noget at sige ham på med hensyn til opførsel.

$\mathrm{Nu}$ havde værten indbudt fremmede til spisning, og det var alle gode venner og bekendte. Lige da de skulle spise, kom obersten hjem, gik gennem stuen, men kom straks tilbage, satte sig ned ved bordet og spiste med, ja, blev i selskabet hele aftenen! Det siger sig selv, at alle var trykkede over oberstens tilstedeværelse, allermest værten. Næste dag sagde han til obersten: "Vi har hidtil tålt Dem, og vi er kommet helt godt ud af det, når vi nu skulle være sammen! Men det, der skete i aftes, er meget, meget pinligt. Det ødelagde hele aftenen for mig. $\mathrm{Nu}$ mener jeg, det gode forhold må være forbi!«

Herpå svarede obersten: »Jeg var med vilje til stede hele aftenen for Deres skyld, for at der ikke skulle blive sagt noget, der kunne komme til at skade Dem, hvis det kom videre. For ... iblandt Deres venner ... var nemlig én, hvem jeg i går havde udbetalt $2000 \mathrm{kr}$. som stikker!«

Søndag den 17. december 1944. Mindegudstjeneste for lektor Rosenkjær i Tønder kirke. Bertel, Svend, Inge, Harald og jeg deltog. Kirken var stuvende fuld. Vi følte, at det ikke her var en enkelt skæbne, der var draget frem. Danske fra Tønder og hele omegnen var forsamlede. Vi sad lige over for to gendarmkoner fra Sæd, meget, meget grebne og bevægede, idet deres tanker jo gik til deres mænd i Tyskland. 
Vor faldne slægt, hvor trænger den til frelse!

Vor onde slægt, hvor trænger den til skjul!

Vor syge slægt, hvor trænger den til helse!

Vor bange slægt, hvor trænger den til jul!

Dagen før juleaften: Vagtmester Andersen kommer hjem. Husmor var for 3. gang til stationen $\mathrm{i}$ jumben for at hente hjemvendende gendarmer. Alle havde håbet, at gendarmerne kom hjem til jul. Men nej, nu bliver de flyttet fra Neuengamme til lejre ved Dresden.

Ved julemødet 4. juledag i vort lille forsamlingshus mindedes formanden (Axel) gendarm Jens Petersen. Ved børnenes juletræ 5. juledag sagde Axel også noget om gendarmerne: „Vi savner vore gendarmer! Hvad er Lydersholm uden gendarmer? Som en vinter uden sne, lærker uden sang, sommer uden sol! Vi håber inderligt, at de snart kommer hjem! De fleste gendarmkoner fik julekort fra deres mand.

Den 7. januar 1945. Mindegudstjeneste i Burkal præstegård for overgendarm Jens Petersen. Pastor Ejnar Høgel vandt mange hjerter, taler smukt, varmt og naturligt! Dygtigt også; det må huskes, at en del af familien har været og er tyske. Hjemmetyskerne mødte, underligt nok, og dog! Det må nemlig understreges, at her i Lydersholm har det altid været skik, at hvad der end til daglig skiller os: ved begravelser (her fra byen) møder alle beboere. Over for døden er alle lige. Toldforvalter Harald Bahnsen, Tønder, talte på etatens vegne, overgendarm Schultz på gendarmernes vegne: "Vi fulgtes til Frøslev, så skiltes vore veje. Det var tungt for os, da kammeraterne kørtes sydpå«.

Den 7. januar 1945. 3 gendarmdødsfald, deriblandt vagtmester Søren Schmidt, tidligere Lydersholm. En personbil beskudt af allieret flyver ved Stemmild.

Den 12. januar. Vagtmester Bruun kommen hjem fra Frøslev. Kaptajn Ørsted Petersen og overgendarm Andreasen, Sæd, kom ligeledes hjem.

Den 20. januar. 6 gendarmdødsfald, ligeledes politimester Agersted, Åbenrå. Rygterne svirrer: det berettes nu, at i Tyskland brugtes gendarmerne som bloddonorer. Et stort antal fanger er ført fra Frøslev til Tyskland som gidsler, deriblandt Erik Svendsen, Holger Petersen og lærer Marcussen.

Februar. En bagermesterfrue fra Tønder arresteret. Sad først i den tyske skoles kælder, senere på Koldinghus. Man beretter, at hun ved en fest på Tønderhus havde fået rigeligt, rakte tunge ad en tysk officer, der boede på Tønderhus, da han samlede hendes handske op. Officeren 
tilbød at lade det skete være glemt, hvis hun ville give en undskyldning, men hun blev ved at skælde ud; ja, ringede ovenikøbet officeren op, på hans værelse, og fortsatte. En sådan opførsel måtte hævne sig.

350 tyske arbejdere ankommer til Jejsing-Rørkær for at grave tankgrave og skyttegrave, fælder, på strækningen Jejsing-Tønder.

På Krusågård er over 200 arbejdere i gang med gravning, gennem køkkenhaver henover markerne. De sover i halm, i forsamlingshuset og skolen. Der er $650 \mathrm{i}$ alt i sognet, 5 er over 70 år.

Marts: Flygtninge fra Østprøjsen strømmer i massevis til egnen. Til Tønder kom 1500. De indkvarteredes hos hjemmetyskerne $\mathrm{i}$ by og på land. Til Lydersholm kom 30. Ellers boede de i lejre, hvorfra de sendtes ud til arbejde på gårdene. Her på gården kom 2-3 kvinder og en gymnasiast, der havde mistet mor og bedstemor på flugten og nu stod uden familie. De var her i 14 dage.

Slesvig bys garnison er nu i Burkal: i forsamlingshus, kro, skole, Rens efterskole, Jyndevad skole og i Bylderup. I Jejsing er der sårede soldater i forsamlingshuset. Indkvartering hos private: hos hjemmetyskerne og enkelte danske.

En vinteraften blev en engelsk flyvemaskine skudt ned på en mark ved Jejsing. 6 flyvere blev dræbt. Maskinen og de døde englændere blev liggende $\mathrm{i}$ to døgn. Folk valfartede for at se det. Den tyske skole i Bylderup kom med læreren i spidsen for at beundre tyskernes værk. Hvor utiltalende at lade de døde ligge så længe. Det viser ringe respekt og pietet over for døden. Én flyver sad fast i en tjørnehæk. Skoledrenge gik og samlede flødekarameller ud af flyvernes lommer.

Det var vel naturligt, at også Svend tog derop. Han havde fået øje på en brevdue i et bur og anstrengte sig af yderste evne for at få den fat. Tænk, om han kunne sende den af sted hjem med melding! Men efterhånden var der kommen vagt!

En bombe ramte et hus i Rens. En bombe faldt i Nolde, en ved Vindtved, en syd for Jejsing, en i Solderup og nogle syd for grænsen. Alle steder mærkedes rystelserne, og hørtes drøn. Grøngård lå netop i centrum af denne cirkel, uskadt!

På hele strækningen til Tønder blev gravet firkantede maskingeværstillinger, et par meter fra landevejen og med ca. 50 meters afstand.

Kl. 8 morgen ringede telefonen: om Grøngård kunne hente 4 gendarmer, der netop var ankommet til Jejsing, lige fra Neuengamme. Hesten blev igen omgående spændt for jumben, og mor selv kørte igen. Hos købmand Andresen var overgendarm Karl Larsen og gendarm Hans Skovmand, aspiranterne Kr. Paulsen og Peter Larsen. Stor bevægelse! 
aldrig har jeg oplevet et så bevæget møde og køretur. Da vi kørte ud af Jejsing by, så vi nogle tyske soldater spille fodbold på idrætspladsen ved forsamlingshuset. Ikke et ord lød derom, men overgendarm Larsen græd ved synet.

Folk, vi mødte, vinkede! Ved Bimpel, Grøngård, Lille Grøngård stod alle uden for og hilste: velkommen hjem; ja, ved hvert dansk hus i Lydersholm. Da alle skolebørnene kom løbende os i møde, græd Larsen, tårerne løb lige så stille. Det var et gribende syn, da fru Larsen og datteren kom cyklende os imøde. På vejen derop havde jeg tænkt på alt det, jeg nu skulle huske at spørge om, men ... det hele blev så gribende, at man blev helt tavs.

To hjemmetyskere fra Jejsing og en gårdmand fra Rørkær kørte $\mathrm{i}$ går middags mod nord med hver sin arbejdsvogn og spand heste. Det forlyder, at de skal til Esbjerg og være med blandt de 8000 mand, der skal lave fæstning; overnatte i Rejsby. Det forlyder også, at de skal til Rejsby og lave dige, for man venter, at englænderne skal gå i land $i$ løbet af kommende uge. Fra Tønder er der allerede afrejst mange hjemmetyskere, også kvinder. En hjemmetysk kone fortalte, at de kvinder, der kan holde ud at grave, også skal grave; de andre kan lave mad. Også i forholdet til vore hjemmetyske naboer bliver det en ganske overordentlig spændende tid, vi går $\mathrm{i}$ møde. Hvordan mon det vil udvikle sig?

Den 21. april 1945 ankom en ny »daglejer « til Grøngård: Hans Jensen fra Rødding. 8 dage senere kom endnu en daglejer, Kette. Han sover dog om natten hos naboen ... Det var politibetjentene P. E. Møller og Schmidt fra Tønder. Tønder politi var, som overalt i landet, "gået under jorden«. Nu havde man hele politistyrken samlet $\mathrm{i}$ umiddelbar nærhed af Tønder. Som hemmeligt samlingssted havde betjentene Margrethegård.

Ingen vidste, at de var politibetjente. Gestapo havde flere gange søgt dem i deres hjem. Aften efter aften, nat efter nat. Folk fik det først at vide bagefter. Det var godt og modigt gjort af familien P. Petersen at være værter og lukke deres hjem op, i den farefulde og yderst spændende tid.

Den 4. maj 1945 om morgenen cyklede jeg til Tønder sammen med skolebørnene. Lidt senere mødte jeg Inge på gaden: »Rektor har givet eleverne fra landet fri til at køre hjem, for englænderne kan ventes ved grænsen nårsomhelst «. Så blæstes der til luftalarm i Tønder! Vi snuppede cyklerne og for ud af byen. En stor folk engelske flyvemaskiner kom sydfra. Nogle fløj meget lavt, nogle dykkede ned over Sæd, og 
maskinpistolerne knaldede. Vi smed cyklerne; her lå vi så alle i grøften, i største spænding, mens maskinerne fløj over vore hoveder. Det blev første og sidste gang, jeg måtte i grøften.

Kort efter at vi var kommet hjem, godt middag, lød den hemmelige kode pr. telefon til daglejerne »mød os nu«. Sammen med forvalteren Harald forlod de pludselig gården.

Husbond var indkaldt til fortroligt møde på Det danske Kontor i Tønder. Inger Enemark bad ham om endelig at komme. Et par hundrede frihedskæmpere var gennem to år uddannet nordpå og var nu fra nord for Skærbæk på vej til grænsen. Lige så snart englænderne havde passeret grænsen, skulle frihedskæmperne overtage grænsebevogtningen. 60 mand skulle bo her på Grøngård, og vi skulle skaffe dem mad!

Under hele krigen havde vi et Europakort på væggen i Borgestuen. Vi flyttede knappenålene, efterhånden som de allierede hære rykkede fremad. Nu blev det spændende, om englænderne ville rykke frem fra Hamborg for at befri Danmark, eller om russerne fra Mecklenborg ville sætte over til Lolland og Falster. Rygter igen: Englænderne har passeret grænsen og er i Åbenrå! Russerne er på Fyn! Skulle vi få krigsskueplads, netop her ved grænsen? Spænding! Uro i sindet! Alligevel ro!

\section{Befrielsen}

Den 4. maj kl. 8.30 aften. Danmark atter frit! Straks efter radiobudskabet hejste Max Dannebrog! Det var en lettelse, at det nu var afværget, at Danmark blev indtaget efter kamp, af dem, der kom først.

Hele befolkningen ventede utålmodigt på Montgomery og hans ørkenrotter. Både en og to aftener, før der kom englændere til Sæd, cyklede folk derhen efter rygter om, at »englænderne er ved grænsen«.

Den 5. maj $1945 \mathrm{kl}$. $7 \frac{1}{2}$ om morgenen mødte overgendarm Peter Hansen og Math. Christiansen her for sammen med husbond at drøfte indkvarteringen af de 60 frihedskæmpere, der nu kunne komme ud i private hjem. Kl. 8 ringede kirkeklokkerne over hele landet. Klokkerne fra Burkal kunne vi desværre ikke høre her på Grøngård; afstanden er for stor.

Over middag cyklede vi alle til Tønder. En aldeles overvældende jublende glæde prægede den danske befolkning. Lige uden for byen var der landet en engelsk flyvemaskine; her var fuldt af folk, der alle skulle se! Axel Bentholm var også henne og pille ved et målebordsblad eller kort, for at se, hvad det nu var lavet af. »Ikke pille ved maskinen«, 

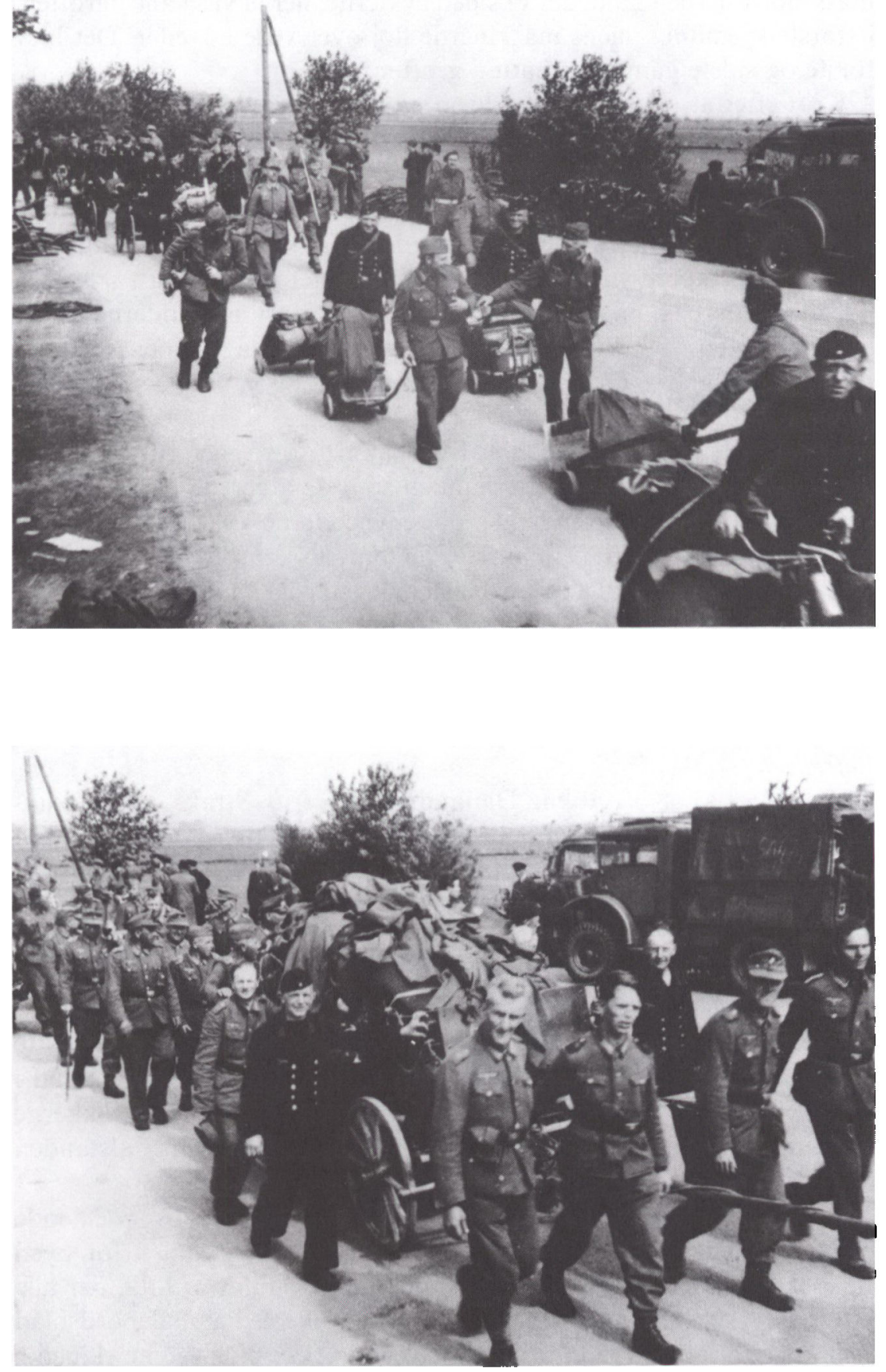
lød en bøs stemme. Det var Svend, der som frihedskæmper stod vagt der. Hans far blev vel nok overrasket og en lille smule stolt ved at se sin søn som frihedskæmper; han havde intet anet derom. Svend var dengang discipel på apoteket $\mathrm{i}$ Løgumkloster.

De frihedskæmpere, der var på vej nordfra til grænsen, kom i kamp med tyskerne ved Skærbæk. To dræbtes, nogle såredes. Ved grænsen ved Bremsbøl blev tre frihedskæmpere alvorligt såret ved, at tyske pansernæver blev kastet lige ind på dem. Blandt dem var to ingeniører i Statens Jordlovsudvalg: Heron Nielsen, der fik maveskud og Christensen, der fik højre arm ødelagt. De lever begge.

Tyske soldater begyndte at gå hjemad flere dage før kapitulationen. De samledes i flokke i Grøngård skov; mange gik her forbi gården og over grænsen ved Bejers kro. De havde våben endnu!

Lørdag nat, den 5 . maj kom 4 tyske soldater herind i bryggerset. Forvalteren havde sit værelse med dør til bryggerset. Han vågnede af uro og støvletramp, lukkede døren op og gik $i$ sin seng igen. Her lå han og forhandlede med soldaterne; de spurgte, om de kunne komme over grænsen. "Ja«, sagde Harald, »men ikke bevæbnet! $\mathrm{Og}$ de måtte skynde sig, for her var indkvarteret 60 frihedskæmpere, de sov i laden. Axel hørte uroen og råbte: »Hvad er der løs?« »Uha«, sagde Harald, »nu står frihedskæmperne op! « Soldaterne smed alt, hvad de stod med af geværer, pistoler og ammunition og stak af, sydpå. Underligt! en forandring var sket. En mand, liggende i sengen, afvæbner 4 tyske soldater.

\section{Befrielsessommeren}

Søndag den 6. maj 1945 kl. 9 aften kom kaptajn Digmann pludselig herind i stuen: "Jeg har 60 mand til Dem herudenfor!« Alle stod ret uden for hovedtrappen. Dybt grebne blev vi, da Digmann udtalte, at de alle kom direkte fra Frøslevlejren. Inden de skulle rejse til hver sit hjem, havde de meldt sig frivilligt til en tørn som grænsevagt i 14 dage.

"En dag log oversergent Yde Sorensen husmor med til Tonder for at se englandernes afvabning af de tyske tropper inden fortsattelsen over gransen. Alt blev nasten taget fra soldaterne. De stod $i$ endelese rakker sd langt ojet kunne se. Deres ejendele, vel også worganiserede ejendelew, havde de pakket sammen og lagt i alle mulige og umulige små køretøjer lige fra lobehjul, dukkevogne, barnevogne, trakvogne til lidt storre, som flere soldater trak og skubbede. Underligt at std og betragte alt dette" - sådan kommenterer fru Bentholm billederne af de tyske tropper pd vej sydover. (Foto i Anna Rud Bentholms privatarkiv, Landsarkivet for de sonderjyske landsdele) 


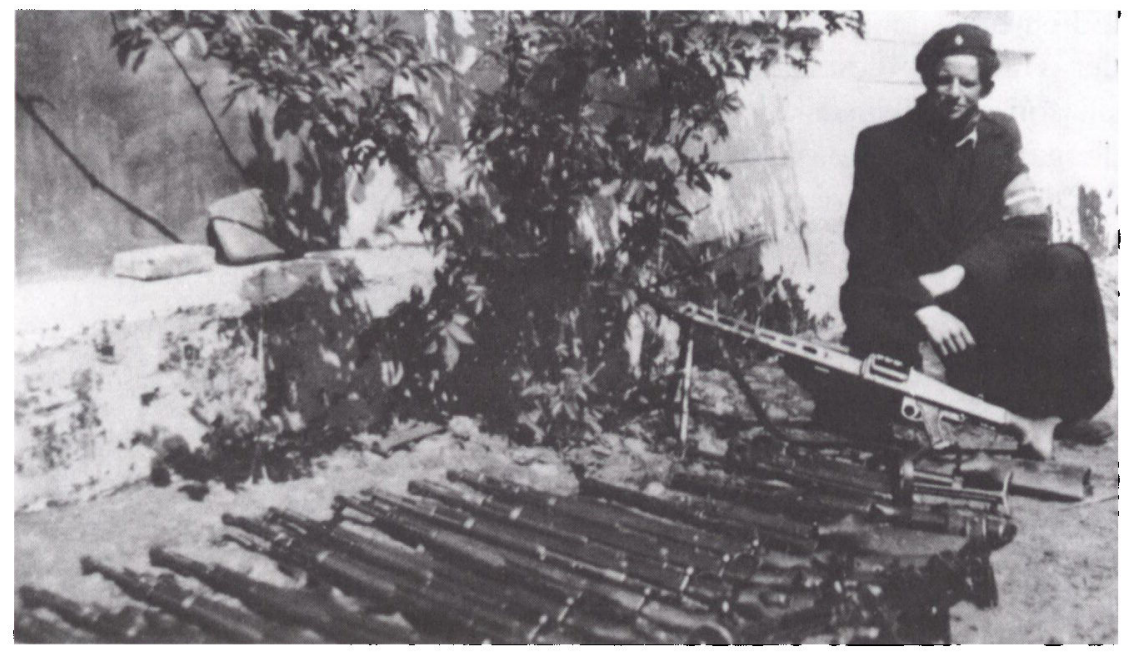

En frihedskamper holder "våbenskue" på Grangård. (Foto i Anna Rud Bentholms privatarkiv, Landsarkivet for de sonderjyske landsdele)

Det øsregnede og blev efterhånden bælgmørkt. Men alle vagterne skulle på posterne omgående. Resten blev indkvarteret rundt om $\mathrm{i}$ hjemmene. Først bød Axel dem dog alle et hjerteligt velkommen ude i loen.

Det blev langt over midnat, inden vi her på gården fik vor aftenkaffe og kom til ro. Vi havde 3 frihedskæmpere indkvarteret, premierløjtnant Torben Tryde, som chef, kommandoofficiant H. A. Nielsen og telefonvagtmester $F$. Andersen.

Frihedskæmperbataillonen formeredes i 4 kompagnier. 3. kompagni skulle påtage sig Jyndevad-Rens-Lydersholm. Styrken blev indkvarteret hos beboerne $\mathrm{i}$ Lydersholm og ordren blev: "Ingen overgang på andre steder end ved Rens og Sæd. Hver tysker må medføre ét håndvåben, alle andre våben beslaglægges. Til transport af levnedsmidler eller syge må kun medføres én vogn pr. bataillon.«

Ordre fra grænsekommandoen: Byg en barrikade lige nord for Bimpel. Vejen mod Lydersholm spærres med barrikade af jord, græstørv, sten og vogne.

Ved ankomsten hertil var kun hver tredje mand bevæbnet. Men snart strømmede det ind med geværer af alle slags, maskinpistoler, pistoler og meget andet. Alt taget fra tyskerne.

Hver gang frihedskæmperne havde anholdt tyskere, kom de her til 
hovedkvarteret med dem. Hvor var det interessante dage, fra morgen til aften, ja, natten med! Det var helt fantastisk, som der blev skudt mange skud, døgnet rundt. Fra alle mulige kanter lød der skud, ikke et enkelt, men $\mathrm{i}$ hundredvis. Man øvede sig! Ammunition fandtes liggende smidt overalt i grøfter og ved veje. En dag kom et hestekøretøj ind på gården for at søge beskyttelse. Kuglerne var faret tværs over vejen, hvor de kørte.

Daglig fik jeg talt med frihedskæmpere, vel med dem alle. Det var uhyre interessant at høre, hvad hver enkelt havde oplevet. Premierløjtnant Tryde var bleg, hulkindet og sammenbidt; havde kun været ét døgn i Frøslev, ellers $\frac{1}{2}$ år i Vestre Fængsel, med klø efter noder. Premierløjtnant Lind var mishandlet på det grusomste. Han havde bl.a. siddet i universitetets kælder i Århus i 3 måneder med hænder og fødder lænket sammen. Beretninger af denne art læser man om andre steder. »Hovedpersoner" levede op her, i friheden, i sommer og sol!

I vort lille forsamlingshus havde vi en sammenkomst for beboere og frihedskæmpere; en aften med fuldt hus, som vi sent vil glemme. Om dagen havde frihedskæmperne været til afskedsparade i Tønder. Af grænsekommandoen havde hver mand modtaget $5 \mathrm{kr}$. til at dække eventuelle småudgifter med.

Seminarielærer Claus Eskildsen holdt tale om Sønderjylland og Sydslesvig. Flere havde ordet, bl.a. premierløjtnant Tryde. Med varme ord udtrykte han frihedskæmpernes tak og bad beboerne modtage $250 \mathrm{kr}$. til forsamlingshuset som gave fra frihedskæmperne. Pengene var de 5 kr., som hver mand havde fået $\mathrm{i}$ Tønder. Axel Bentholm takkede som formand for gaven. Pengene blev brugt til et maleri af kunstmaler C. S. Tønder med motiv fra Lydersholm. Billedet hænger i forsamlingshuset.

Kristi Himmelfartsdag kom de første englændere herind på gården. Ved middagstid kom en kaptajn og hans underofficerer direkte fra Hamborg, bare over grænsen for at se Danmark og hilse på danskerne. Vagten omkring Grøngård viste dem herind; vi blev glade og bød dem indenfor. Da kaptajnen stod i døren, spillede jeg på klaveret "God save the King" pompøst, langsomt og med varme. Tryde og officeren stod ret. Tårerne løb stille ned ad hans kinder; han takkede meget bevæget. Efter $1 \frac{1}{2}$ times ophold, med middagsmad og megen snakken, kørte de tilbage.

Den 14. maj 1945 ankom 45 mand af den danske brigade fra Sverige. 4. bataillons 2 . kompagnis 2 . deling af brigadens sydjyske kommando overtog grænsebevogtningen på strækningen fra Flyvsholm i øst til grænsesten nr. 195 vest. Denne deling var her til 17 . maj. 


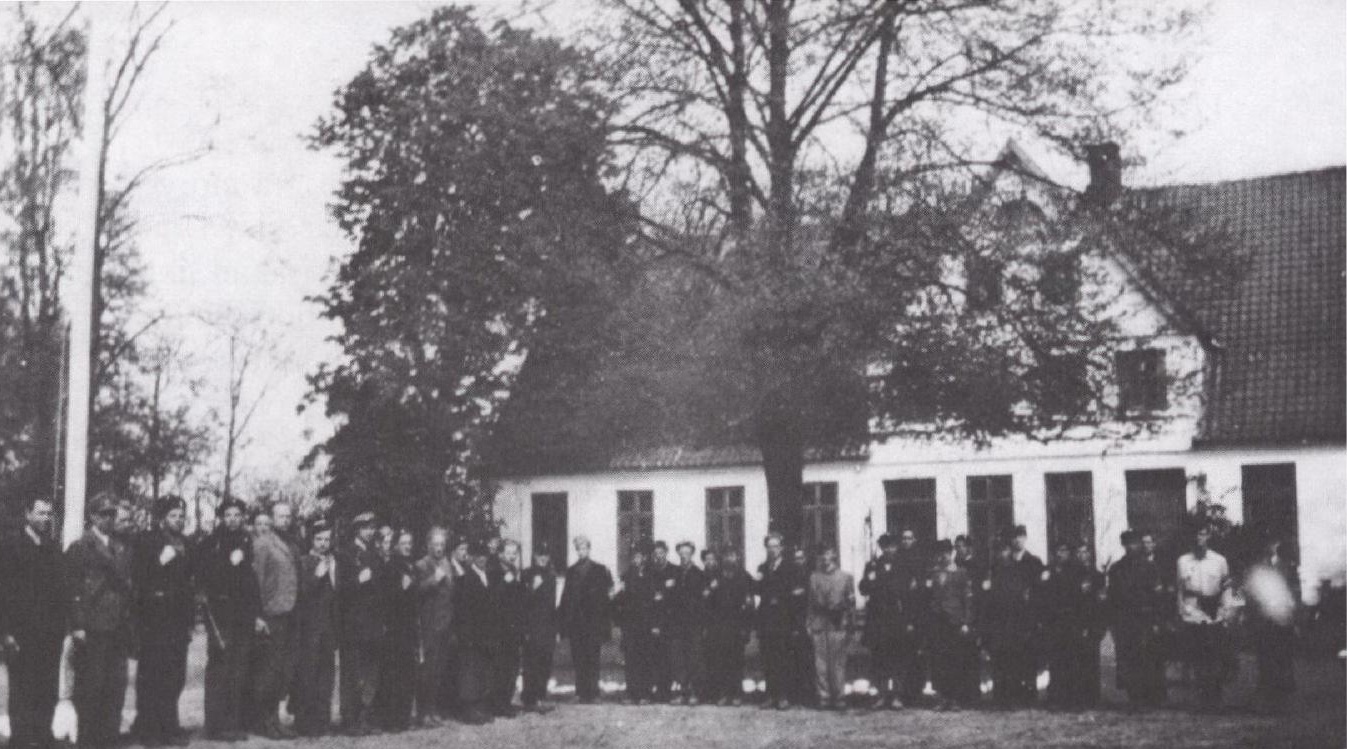

Frihedskampere på Grongdrd i maj 1945. (Foto $i$ Anna Rud Bentholms privatarkiv, Landsarkivet for de sonderjyske landsdele)

16.-18. maj ankom 2. bataillons 4. kompagnis 3. deling under premierløjtnant Hegnhøj. 18. maj til 8. juli var det 4. bataillons 1. kompagnis 1. deling under premierløjtnant Severinsen med oversergent Yde Sørensen som næstkommanderende. 45 mand boede her på Grøngård. På gæsteværelserne var officererne og to lotter. Mandskabet boede dels i 3 barakker på gårdspladsen, dels i halm på 1. sal af svinestalden. I begyndelsen havde de kontor $\mathrm{i}$ vor stue, men senere overlod vi soveværelset lige ved forstuen til kontor med egen telefon for brigaden. Det var urolige dage og urolige nætter; men hvor var det interessant at opleve! Brigaden havde uddannet sig i de svenske skove, og var faktisk indstillet på krig og kamp. De følte, der skete for lidt her. Grænsebevogtning var for ensformig for mange af dem.

En dag holdt brigadens to øverste officerer skydeøvelser ind i en mægtig stor, våd halmstak, der stod lige tæt ved laden. Derefter kørte de herrer til Tønder. Straks skulle mandskabet komme i gang: de skød og skød, vist med lyskugler. Om aftenen begyndte stakken at brænde. Brigaden arbejdede af alle kræfter for at få ilden slukket. Vor dejlige gamle lade var virkelig i fare. I lange rækker stod de tværs over gårdspladsen og lod spande med vand gå fra hånd til hånd. Man svedte, og det hele gik ikke stille af. Heldigvis kom premierløjtnanten og oversergenten hjem. Yde tog straks kommandoen. Civilforsvarets 
udrykningstjeneste blev kaldt til assistance; branden blev slukket. Der havde været stor forvirring, til dels dårlig samvittighed og skumle fornemmelser. Husbond var faktisk den mest rolige; tilsyneladende da!

Den anden dag havde husbond meget travlt med at passe nogle små lam i fårehuset. Pludselig løb tårerne ud af øjne, næse og mund; det var frygtelig irriterende, og han måtte afbryde. Men så opdagede han, at to korporaler stod lige uden for og legede med, prøvede, en tåregasbombe. Da var det vel nok husbond, der agerede kaptajn. Ordstrømmen stod ihvertfald ikke tilbage for chefens kommando!

Den 8. juli 1945 kom livgarden for at overtage grænsebevogtningen, i alt 150 mand, som alle boede på Grøngård den første nat. Næste dag blev de tre barakker på gårdspladsen flyttet ned ved den tyske skole. Garderne begyndte straks at bygge en rigtig lejr, og her blev nu hovedkvarter for grænsevagten. Garderne blev indkvarteret $i$ private hjem og hjalp til med høstarbejde og redningsarbejde, f.eks. da der brændte en gård i Lydersholm.

Fordelt på to hold besøgte hele besætningen i alt 60 mand på kongeskibet Dannebrog Grøngård den 31. august og 1. september 1948. Kongeskibet lå i havn i Sønderborg, kongeparret boede på Gråsten slot. Min bror Holger Rud var overlæge på skibet. Første dag kom »dronningens kvarter«, anden dag kom »kongens kvarter«. Det var

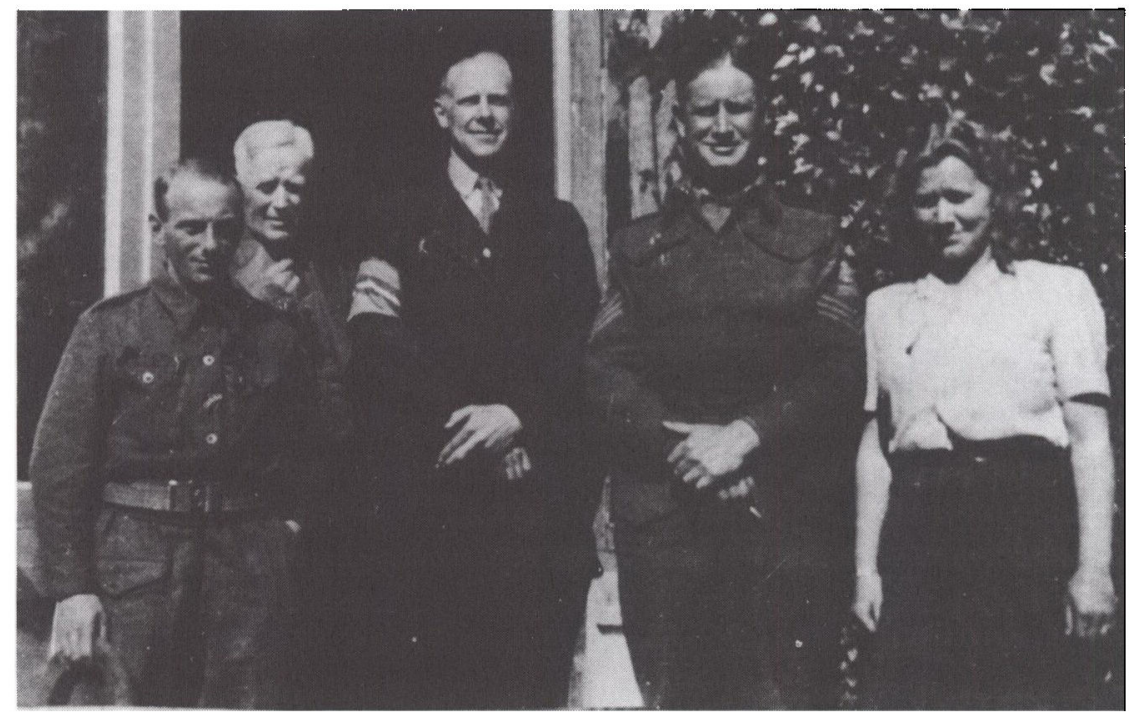

De forste englandere på Grøngård, Kristi Himmelfartsdag 1945. (Foto i Anna Rud Bentholms privatarkiv, Landsarkivet for de sonderjyske landsdele) 


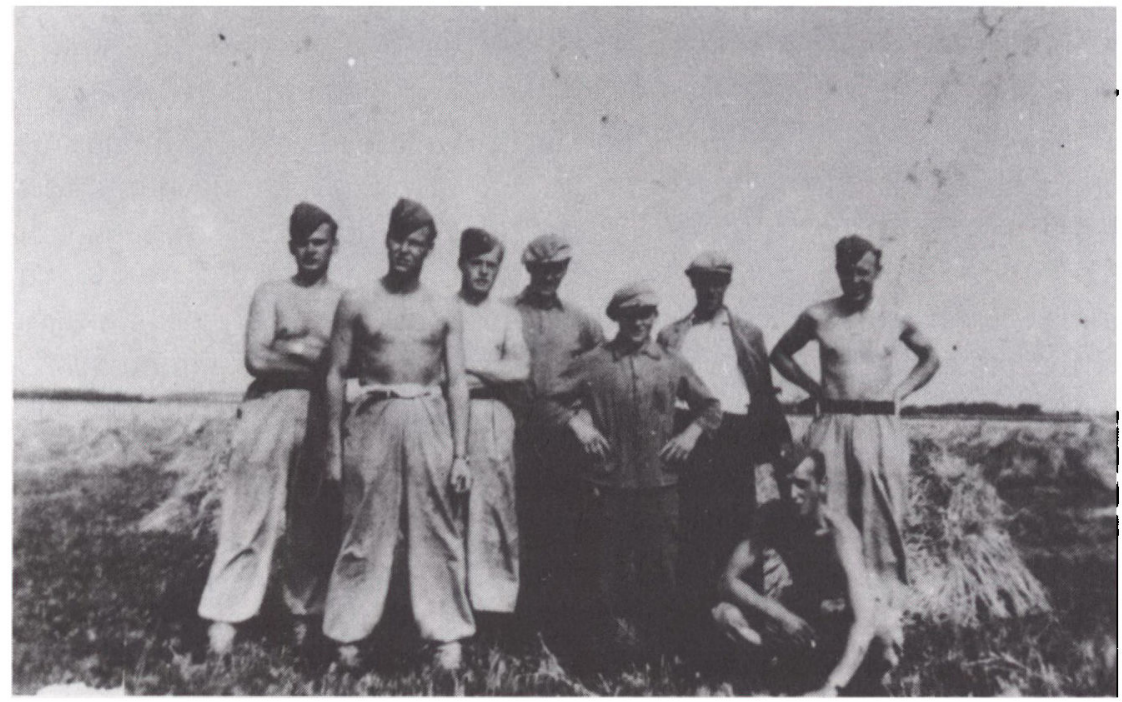

Gardere på hostarbejde pd̊ Grongård i 1945. (Foto i Anna Rud Bentholms privatarkiv, Landsarkivet for de senderjyske landsdele)

flinke, raske gutter og tiltalende officerer. De bragte lystighed og liv med herud på gården. I havestuen og haven blev der spist medbragt frokost og serveret kaffe med friskbagt wienerbrød, "husets specialitet« bestilt af Holger Rud. Alle marinesoldaterne legede blindebuk, sækkeløb, tovtrækning og mange andre lege $\mathrm{i}$ haven. Jeg tror, at begge parter fandt, at det blev en fornøjelig og morsom eftermiddag.

Forbindelse med de danske lige syd for gransen

En eftermiddag en gang før 1940 ankom en stor rutebil syd fra til Grøngård med deltagere fra Agtrup, Ladelund, Vestre, Ellehoved og Sønder Løgum med lærer Gustav Lindstrøm i spidsen. Først blev gæsterne fordelt omkring i hjemmene, hvor værterne ventede med kaffe. Sidst på eftermiddagen tog de fat på generalprøven. Stykkerne var indøvet rundt omkring $\mathrm{i}$ hjemmene. Alle dilettanterne havde lagt et stort arbejde i det, flere havde cyklet mange kilometer til øvelse.

Efter aftensmaden opførte de to små stykker i Lydersholm forsamlingshus. Efter spillet måtte scenen tages ned. Der er som bekendt ikke megen plads i den lille træbarak. Gulv og kulisser, det hele op på loftet gennem en lem. Resten ud af vinduet. Man måtte drikke kaffe holdvis. Der blev sunget og holdt mange taler. Lindstrøm læste op. Til sidst begyndte dansen. 
Bodil, en ung pige fra Grøngård, tog en vinter igennem over grænsen ved Bejers kro. Hun trodsede sne og storm for at lede gymnastik i Ladelund.

Ved et Sankt Hans bål i Lydersholm har lærer Chr. Stenz, Ladelund, holdt båltale. Nogle danske syd for grænsen sendte bålhilsen med at tænde deres Sankt Hans bål på samme tid.

Ikke så få familier har pårørende på begge sider af grænsen. En familie havde aftalt, at hvis der kom grænsespærring, ville de mødes en bestemt sommersøndag 1945 på selve grænsen ved Bejers kro. Ca. 20 familiemedlemmer mødtes en hel dag. Familien her fra Lydersholm havde fortæring med til alle måltiderne. Mod aften gik de hver til sit.

Lærer Edsen Johansen, Jelling, var født i Vestre, hvor faderen var maler, og har som barn tit og ofte været sendt til Lydersholm efter malervarer. I sommeren 1945 kom han, 83 år gammel, cyklende sammen med en søn helt fra Jelling. Nu håbede han på at kunne gense barndomshjemmet. Men! til grænsen og ikke længere! Længe stod han, tavs og tankefuld, og skuede mod syd over Skelbækken. Han var på Grøngård og talte bl.a. om »e Storstrøms brusen«. Nu måtte han her foreløbig nøjes med at tegne en skitse af barndomsegnen derover mod Vestre. Han er kendt for sine tegninger i Dansk Børneblad. Så cyklede han atter tilbage til Jelling.

Aftenen før valget 24. oktober 1945 var der store blus langs grænsen, en hilsen fra Danmark, fra Lydersholm, som udtryk for fælles håb!

I november 1945 var hele bestyrelsen for husholdningsforeningen i to biler på et to-dages besøg i Sydtønder amt: i Ladelund, Agtrup, Karlum, Brarup og Bramsted. Jeg var formand. Når man tænker på forholdene i Sydslesvig i dag, kan der vist ikke findes noget bedre ord til at sammenfatte det hele end sforkommenhed «. Husene var mange steder $i$ en ynkelig forfatning, da man $i$ lange tider ikke havde kunnet skaffe det allernødvendigste til reparation. Vejene var slette. Alle var blevet fattige. Vi har set mænd over 60 år, der før havde været velhavende, og som nu måtte gå ud på almindeligt landarbejde for en ringe løn. Stuer og møbler var blevet afgivet til flygtninge, og alle måtte bo under indskrænkede forhold. Tuberkulose, kræft og kønssygdomme bredte sig. Ernæringsforholdene havde været meget dårlige, men var dog lidt bedre nu.

I så godt som hver eneste hjem, vi kom i, savnedes en far eller søn, eller de var faldne. Vi var indkvarteret rundt om i hjemmene. Jeg boede en nat hos Chr. Hansen i Agtrup. I begyndelsen havde der været 9 flygtninge indkvarteret, nu var der 3 . To voksne døtre, der begge 
havde været på højskole og husholdningsskole i Danmark, gik hjemme. Det skyldtes bl.a. at så fik man ikke så mange flygtninge indkvarteret. Pigelønnen var kun 30 mark om måneden; det kunne næsten ikke betale sig at slide på tøjet. Karlelønnen var $\mathbf{4 0}$ mark månedlig, dog fik en selvstændig karl knap 100 mark. I Agtrup har der altid været talt dansk, nu breder plattysk sig. Allerede i efteråret 1945 var i Ladelund 30 enten gift eller forlovet med en flygtning. Man hørte dog også nogle eksempler på unge dansksindede sydslesvigere gift med piger nordfra.

I naboejendommen til Chr. Hansen boede to flygtningefamilier; den ene familie måtte altid gennem den andens stue. De blev uvenner; den yderste familie låste døren, så de inderste, med 4 børn, i 2 år altid måtte gå ud og ind af vinduet.

Min værtinde, Caroline, havde mistet to ægtefæller, de er faldet $\mathrm{i}$ Rusland. Hun har to voksne sønner og lever af at strikke. Får 50 mark om måneden og giver $25 \mathrm{i}$ husleje. Før krigen boede Caroline på Vestre mark, lige syd for Lydersholm. Sammen med sin mand og 2 små drenge kom hun over grænsen til julefesterne i vort lille forsamlingshus.

Husholdningsforeningen har i årene op til 1948 haft en opgave i at indkvartere gamle danske sydslesvigere i vore hjem i grænseegnen. En sommer havde Slogs herreds husholdningsforening 18 hold, med 12 personer i hvert hold, 14 dage.

\section{Opbrud fra Grongård}

Jordlovsudvalget havde hele tiden regnet med, at Grøngård skulle sælges. Uanset om man ofrede lidt eller meget på vedligeholdelse, mente de, at de ville få lige meget for gården. I 1957 blev gården mageskiftet med menighedsrådet $\mathrm{i}$ Burkal, og der blev holdt bygningssyn. I protokollen blev bl.a. skrevet, at bygningerne var vel vedligeholdt, om end meget ikke var tidssvarende. Det var Axel, der havde sat en ære i ordentlig vedligeholdelse. På menighedsrådets vegne overtog Karen og Holger Behrens vort hjem og virkefelt.

Den 1. april 1957 flyttede vi ud. Vi købte et lille rødt hus på hjørnet ved gården, midt $\mathrm{i}$ Axels plantninger. Axel fik et aftægtsjob med at administrere og føre tilsyn med Jordlovsudvalgets jorder langs grænsen, i førstningen helt fra Udbjerg over Sofiedal, Eggebæk, Frøslev til Kruså. Senere, efter en sygdomsperiode, kun de 4 sogne Udbjerg, Tønder Landsogn, Hostrup og Burkal. Tit og ofte kom jordlovsudvalgets husmænd for at tale med ham som rådgiver og ven. Daglig kørte han sine ture ud til ejendommene på knallert. 